\title{
Meta-analysis of cardiovascular toxicity risks in cancer patients on selected targeted agents
}

\author{
C. P. Escalante ${ }^{1,1}$ - Y. C. Chang ${ }^{2}$ - K. Liao ${ }^{3}$ - T. Rouleau ${ }^{4}$ - J. Halm ${ }^{1} \cdot$ P. Bossi $^{5}$ •

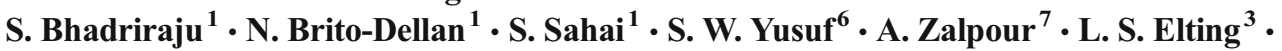 \\ Epidemiology Section of the Mucositis Study Group of the Multinational Association of \\ Supportive Care in Cancer, 2013
}

Received: 22 January 2016 / Accepted: 7 June 2016 / Published online: 25 June 2016

(C) Springer-Verlag Berlin Heidelberg 2016

\begin{abstract}
Purpose The purpose was to estimate the risk and severity of cardiovascular toxicities associated with selected targeted agents.

Methods We searched English-language literature for randomized clinical trials published between January 1, 2000 and November 30, 2013 of targeted cancer therapy drugs approved by the FDA by November 2010. One hundred ten studies were eligible. Using meta-analytic methods, we calculated the relative risks of several cardiovascular toxicities [congestive heart failure (CHF), decreased left ventricular ejection fraction (DLVEF), myocardial infarction (MI), arrhythmia, and hypertension (HTN)], adjusting for sample size using the inverse-variance
\end{abstract}

Presented in part at the MASCC June 2015 Annual Meeting in Copenhagen, Denmark and ASCO Palliative Care in Oncology Symposium in Boston, MA; US, in October 2015

C. P. Escalante

cescalan@mdanderson.org

Epidemiology Section of the Mucositis Study Group of the Multinational Association of Supportive Care in Cancer, 2013

1 Department of General Internal Medicine, University of Texas MD Anderson Cancer Center, Houston, TX, USA

2 Houston Independent School District, Houston, TX, USA

3 Department of Health Services Research, University of Texas MD Anderson Cancer Center, Houston, TX, USA

4 Carolinas Medical Center, Charlotte, NC, USA

5 Fondazione IRCCS, Istituto Nazionale dei Tumori, Milan, Italy

6 Department of Cardiology, University of Texas MD Anderson Cancer Center, Houston, TX, USA

7 Division of Pharmacy, University of Texas MD Anderson Cancer Center, Houston, TX, USA technique. For each targeted agent and side effect, we calculated the number needed to harm. Results: Regarding CHF, trastuzumab showed significantly greater risk of all-grade and high-grade CHF. There was significant increased risk of allgrade DLVEF with sorafenib, sunitinib, and trastuzumab and high-grade DLVEF with bevacizumab and trastuzumab. Sorafenib was associated with significant increased all-grade risk of MI based on one study. None was associated with high-grade risk of MI or increased risk of arrhythmia. Bevacizumab, sorafenib, and sunitinib had significant increased risk of all-grade and high-grade HTN.

Conclusions Several of the targeted agents were significantly associated with increased risk of specific cardiovascular toxicities, CHF, DLVEF, and HTN. Several had significant increased risk for high-grade cardiovascular toxicities (CHF, DLVEF, and HTN). Patients receiving such therapy should be closely monitored for these toxicities and early and aggressive treatment should occur. However, clinical experience has demonstrated that some of these toxicities may be reversible and due to secondary effects.

Keywords Cardiovascular toxicity · Targeted agent . Congestive heart failure - Decreased left ventricular ejection fraction $\cdot$ Myocardial infarction $\cdot$ Hypertension

\section{Introduction}

One of the most significant complications of cancer therapy is cardiovascular toxicity $[1,2]$. This has become especially relevant as newer cancer treatments are developed and are associated with standard treatment or are rapidly becoming alternatives for traditional chemotherapy regimens. As these targeted agents, including monoclonal antibodies and small molecular multitargeted therapeutic agents, have been utilized more frequently 
in a spectrum of both hematological and solid tumors, cardiovascular toxicities have been noted. Specific cardiovascular toxicities include congestive heart failure (CHF), decreased left ventricular ejection fraction (DLVEF), myocardial infarction (MI), arrhythmia, and hypertension (HTN) [1, 3]. Because of these toxicities, delays or discontinuation of cancer treatment and subsequent worsening of cancer outcomes and quality of life may occur. Additionally, they often increase cost of care and utilization of healthcare resources. Therefore, it is important to estimate the risk and severity of cardiovascular toxicities when targeted agents are utilized.

Because of issues in estimating incidence of cardiac adverse effects, the increasing growth in development and clinical usage of these therapies, the small sample sizes sometimes noted in clinical trials with some of these agents, and the impact they may have on the health of the patient, it is imperative that a better understanding of the risks and severity of these various cardiovascular toxicities is examined. Therefore, the objective of this study was to perform a meta-analysis of clinical trials of Food and Drug Administration (FDA)-approved targeted agents to estimate their incremental risks and severity of various cardiovascular toxicities, including CHF, DLVEF, MI, arrhythmia, and HTN $[2,4]$.

\section{Patients and methods}

\section{Search strategy}

We identified 110 English-language randomized trials of 26 targeted cancer therapy drugs approved by the FDA as of November 2010 that had been published between January 1, 2000 and November 30, 2013 in MEDLINE [5]. We expanded our original inclusion dates during our analysis so that we could include as many agents as possible; however, because of the rapid approval cycle for some, more targeted agents were approved after our analysis was complete. In addition, we tried to base our meta-analysis on as many studies available; some agents were fast tracked for approval with only a few papers available. Appendix lists the 26 approved drugs and indications. Although gefitinib was withdrawn from the market in the USA on April 25, 2012 [6], it is used in the European Union [7]. Therefore, it was included in the analysis. Phase II or III randomized control trials, drug names (brand or generic) and their FDA-approved indications (breast neoplasms, colorectal neoplasms, head and neck neoplasms, non-Hodgkin's lymphoma, non-small-cell lung neoplasms, gastrointestinal stromal tumor, etc.) were the keywords used for the literature search. Only studies reporting the results of trials comparing targeted and standard of care chemotherapy regimens were included for analysis. In most cases, this resulted in a comparison of a standard of care chemotherapy regimen to the same regimen plus a targeted agent. However, in a few cases the standard of care was no therapy (post-adjuvant therapy of breast cancer or renal cell carcinoma). Therefore, the comparison is to placebo or no therapy. Finally, in limited cases, most notably with the agent, gefitinib, the targeted agent alone was compared with chemotherapy. Phase I or Phase I/II dose-findings studies, and studies lacking a control group receiving standard of care regimens or without toxicity data, or those reported results from interim or subset analysis were excluded.

Our search retrieved 2496 potentially relevant articles. After excluding review articles, economic evaluation articles, case reports, commentaries, single-arm trials, and phase I trials, 137 articles were identified for review [8-144]. An additional 29 articles were excluded because they were reports of follow-up or maintenance studies or there were fewer than three studies of a targeted drug $[9,10,17,49,56,58,65,76,79-81,93,95$, 97-100, 102, 113, 116, 126-128, 130, 137, 139, 140, 142]. After these exclusions, a total of $108[8,11-16,18-48,50-55$, 57, 59-64, 66-75, 77, 78, 82-92, 94, 96, 101, 103-112, 114, $115,117-125,129,131-136,138,143,144]$ articles describing trials of nine targeted drugs remained for review (Fig. 1). The targeted drugs included bevacizumab, cetuximab, erlotinib, gefitinib, imatinib, lapatinib, rituximab, sorafenib, and trastuzumab. In retrospect, however, we considered sunitinib of such clinical importance that the two trials of this agent were included in the final analysis [127, 128]. With these additions, a total of 110 articles were included in the review (Fig. 1). The majority of the trials used either the National Cancer Institute Common Toxicity Criteria versions 1, 2, or 3 to assess the severity of side effects, while a few trials used the WHO Toxicity Criteria, National Cancer Institute of Canada Common Toxicity Criteria, or New York Heart Association classification.

\section{Data extraction}

Information about trial design (phase II, II-III, or III), regimen, and cardiovascular toxicity for each study were recorded by reviewers. Treatment regimen information included regimen (targeted therapy, chemotherapy, and/or radiotherapy) and total number of patients in each arm. Cardiovascular adverse events were categorized into five groups, including CHF, DLVEF, MI, arrhythmia, and HTN. The toxicity assessment method, assessment frequency, total number of all-grade (1-5) and high-grade (3-5) side effects, number of hospitalizations, and number of deaths also were recorded.

\section{Statistical analysis}

Our goal was to estimate the unique contribution of the targeted drug to the risk of cardiovascular side effects. First, the risk of each side effect for each trial was calculated. Overall adjusted risk for each drug was estimated as a weighted average of risk using the inverse-variance method that took into account the weights of all studies. The risk difference between the targeted regimen and the standard of care regimen 
Fig. 1 Flow chart of literature search and trial selection process
Potential relevant articles using search terms

$(\mathrm{N}=2496)$

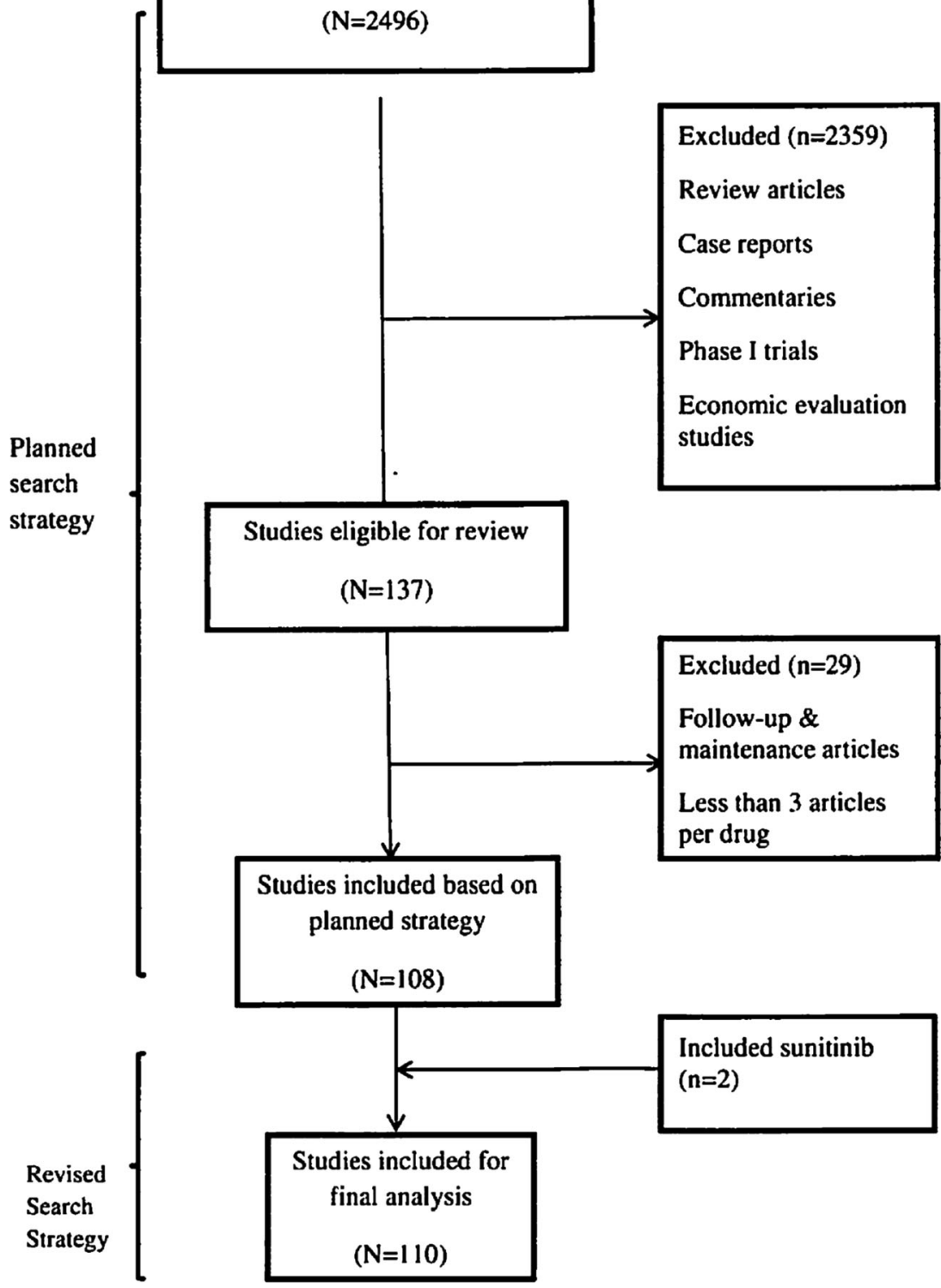

was calculated. Finally, the relative risk of cardiovascular side effects for each agent was computed by utilizing a half-integer continuity correction for studies reporting no events in the treatment or control group. The relative risks and $95 \%$ confidence intervals were derived from Comprehensive Meta-Analysis version 2 (CMA). The number needed to harm $(\mathrm{NNH})$, the reciprocal of the adjusted risk increase, was calculated to provide clinically meaningful estimates of the risk of adverse events of targeted drugs [145].

Heterogeneity of the trials was assessed using Cochran's Q statistic. The assumption of homogeneity was considered invalid when the $p$ value is less than 0.1 , and a random-effects model was used to derive relative risk and $95 \%$ confidence intervals. Otherwise, results from both fixed-effects and random-effects models were considered. A two-tailed $p$ value of less than 0.05 was deemed to be statistically significant.

As previously mentioned, some standard of care control regimens involved no therapy. These studies were combined with others for analysis, but to account for the impact of this difference on the estimates of risk, we computed risk differences and relative risks rather than absolute risk. Relative risk and risk differences should provide accurate measures of the unique contribution of the targeted agent to any regimen (no therapy or chemotherapy) except in the case where the risk of cardiovascular complications with targeted plus conventional chemotherapy is multiplicative (rather than additive). We are not aware of any studies suggesting such a relationship. In a few studies, particularly those involving gefitinib, single-agent 
targeted therapy was compared with conventional chemotherapy. The inaccuracy introduced by those studies is not controlled by the use of relative risk and risk differences. In that situation, we have provided two estimates, one for all studies combined and one from a parallel analysis that excluded single-agent targeted therapy versus chemotherapy.

\section{Results}

\section{Congestive heart failure}

Based on analysis of nine trials for all-grade CHF, trastuzumab showed significantly greater risk (RR 5.8) and had a number needed to harm $(\mathrm{NNH})$ of 9 . This translates into one additional all-grade CHF compared to those patients in the control regimens for every nine patients treated with trastuzumab. Bevacizumab had a RR of 1.8 and NNH of 71 for all-grade CHF while there were no case reported in the one erlotinib study and no studies of lapatinib or lapatinib-parallel analysis.

With regards to high-grade CHF, nine studies were evaluated. Again, trastuzumab had an increased RR of 5.9; for every 14 patients treated with trastuzumab, there was one additional highgrade $\mathrm{CHF}$ compared to those patients in the control regimen. In the one study of erlotinib, there was no case reported. For lapatinib, there was no increased risk of high-grade CHF in the one study evaluated. However, bevacizumab had a RR of 3.5 with a NNH of 71. We conclude that trastuzumab has a significant risk for both all-grade and high-grade CHF in comparison to the other targeted agents studied (Table 1).

\section{Decreased left ventricular ejection fraction}

Twenty-two and 19 trials reported all-grade and high-grade DLVEF, respectively (Table 1). The RR of sorafenib (9.4; $\mathrm{NNH}=6$; based on only one study of 96 patients), sunitinib $(4.3 ; \mathrm{NNH}=11)$, and trastuzumab $(3.0 ; \mathrm{NNH}=5)$ were increased. Cetuximab had a significantly lower risk of all-grade DLVEF $(R R=0.1)$. There was 1 additional all-grade DLVEF for every 25 patients treated with control regimens compared to those treated with cetuximab. No study of erlotinib, gefitinib, or imatinib reported a DLVEF case. Bevacizumab, lapatinib, and rituximab also showed no significant increased risk of all-grade DLVEF.

Trastuzumab had the highest RR $(6.7 ; \mathrm{NNH}=3)$ of targeted agents for high-grade DLVEF. Bevacizumab also had an increased RR of 3.4 with $\mathrm{NNH}=167$. There was no significant increase in risk of high-grade DLVEF for lapatinib, sorafinib, and sunitinib. There were no studies to evaluate cetuximab and sorafenib-parallel analysis, and there were no cases of high-grade DLVEF in the three trials utilizing rituximab. We conclude sorafenib, sunitinib, and trastuzumab had significantly increased risk of all-grade DLVEF while bevacizumab and trastuzumab had significantly increased risk for high-grade DLVEF. Further, cetuximab demonstrated a significant lower risk of all-grade DLVEF compared with standard chemotherapy regimens.

\section{Myocardial infarction}

Two and 6 trials for all-grade and high-grade MI were evaluated, respectively (Table 2). In all-grade MI, there was one study for sorafenib and one study for sorafenib-parallel analysis. Both showed a RR of 11.0 with a NNH of 22; however, the total number $(N=92)$ was small and results should be interpreted judiciously. There were no studies of erlotinib, gelfitinib, rituximab, trastuzumab, bevacizumab, cetuximab, imatinib, lapatinib, and sunitinib reporting all-grade MI cases. There was no significant increased risk for high-grade MI among any of the agents. In conclusion, only sorafenib increased all-grade MI; however this finding was based on only one study of 96 patients.

\section{Arrhythmia}

Three studies for both all-grade and high-grade arrhythmia were evaluated (Table 2). There were no studies of bevacizumab, cetuximab, erlotinib, gefitinib, imatinib, lapatinib, sorafenib, and sunitinib reporting arrhythmia cases. Neither rituximab nor trastuzumab had an increased risk for all-grade arrhythmia. For high-grade arrhythmia, there were no studies reporting any cases utilizing trastuzumab. The three studies evaluating rituximab for high-grade arrhythmia showed no increased risk. In summary, there was no evidence of increased risk of all-grade or high-grade arrhythmia among any of the agents evaluated.

\section{Hypertension}

Based on 35 studies for analysis of all-grade HTN, bevacizumab (RR 5.3; NNH 5), sorafenib-all studies (RR 3.9; NNH 8), sorafenib-parallel analysis (RR 3.6; NNH 9), sunitinib-all studies (RR 7.0; NNH 5), and sunitinib-parallel analysis (RR 5.1; NNH 11) had increased risk (Table 3). Trastuzumab had no studies reporting cases. Similar findings were noted in the 45 studies evaluated for high-grade HTN. Bevacizumab (RR 6.7; NNH 14), sorafenib-all studies (RR 4.4; NNH 20), sorafenib-parallel analysis (RR 5.0; NNH 19), sunitinib-all studies (RR 10.3, NNH 11), and sunitinib-parallel analysis (RR 8.4, 143) all had increased risk for high-grade HTN. We conclude that bevacizumab, sorafenib, and sunitinib have significantly increased risks for both all-grade and high-grade HTN. In addition, parallel analyses of subsets of studies with sorafenib and sunitinib excluding those examining single-agent targeted therapy versus chemotherapy showed very consistent results when compared with analyses including all studies. Figure 2 notes the relative risks of cardiovascular toxicities. 


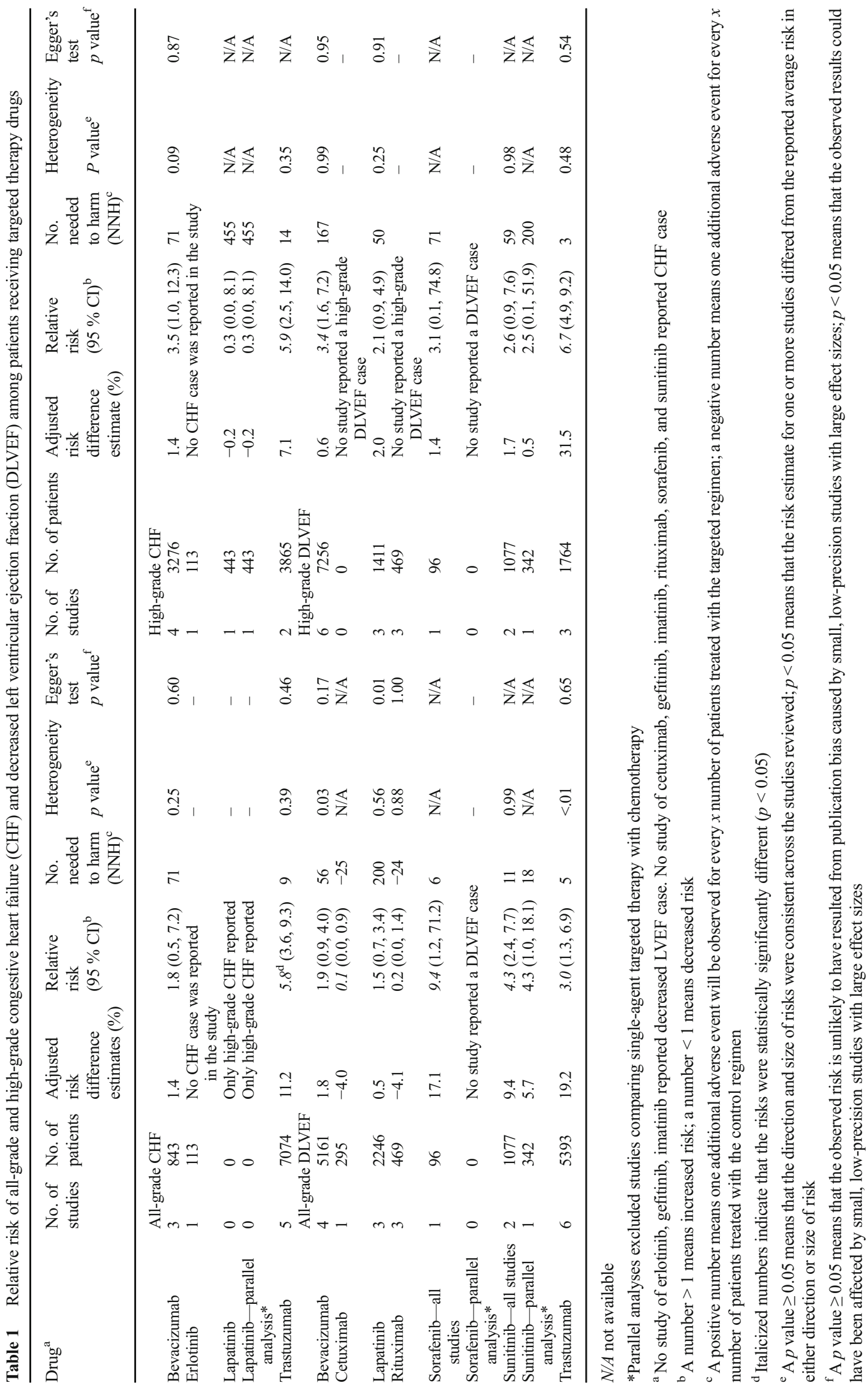




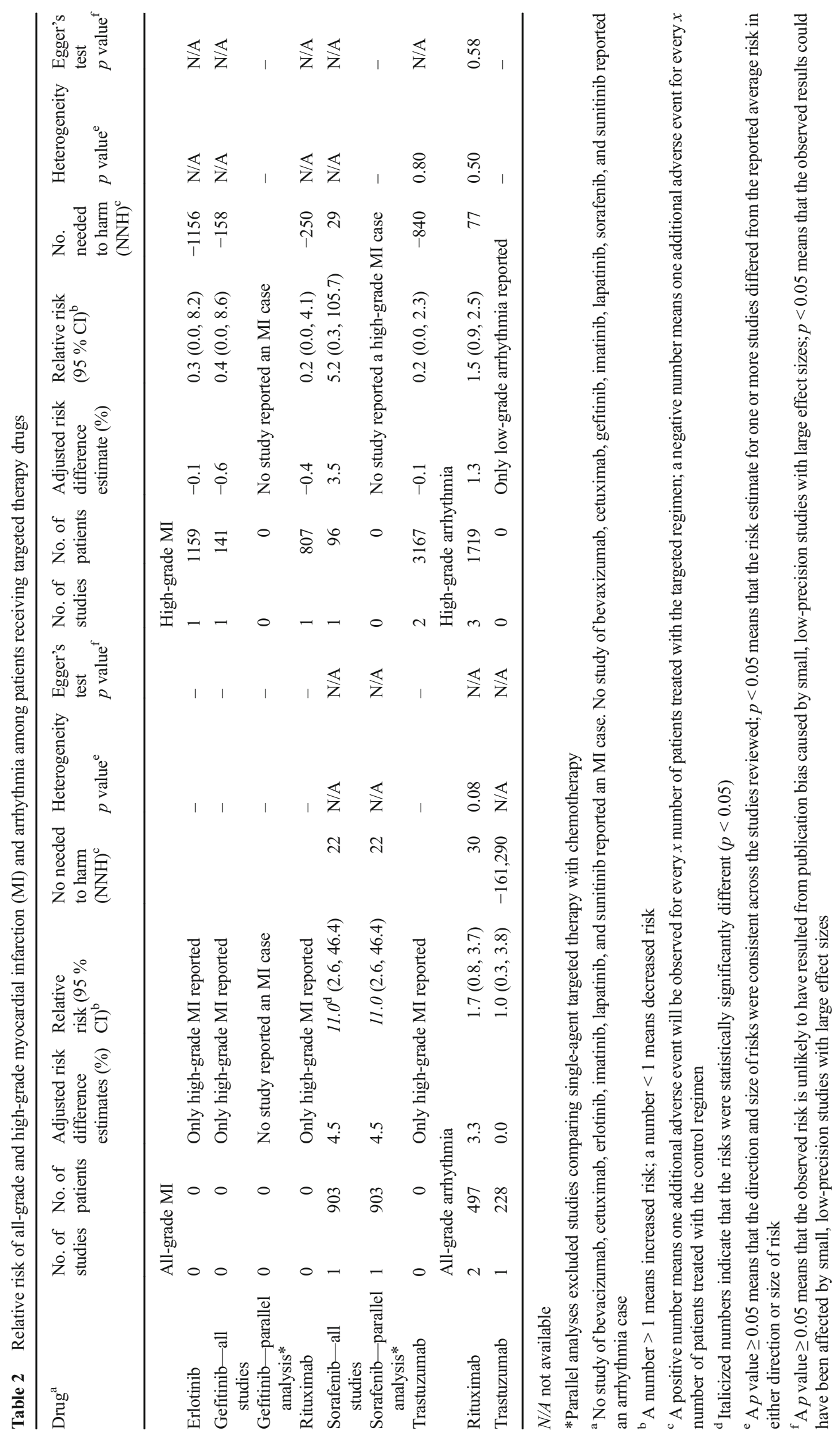




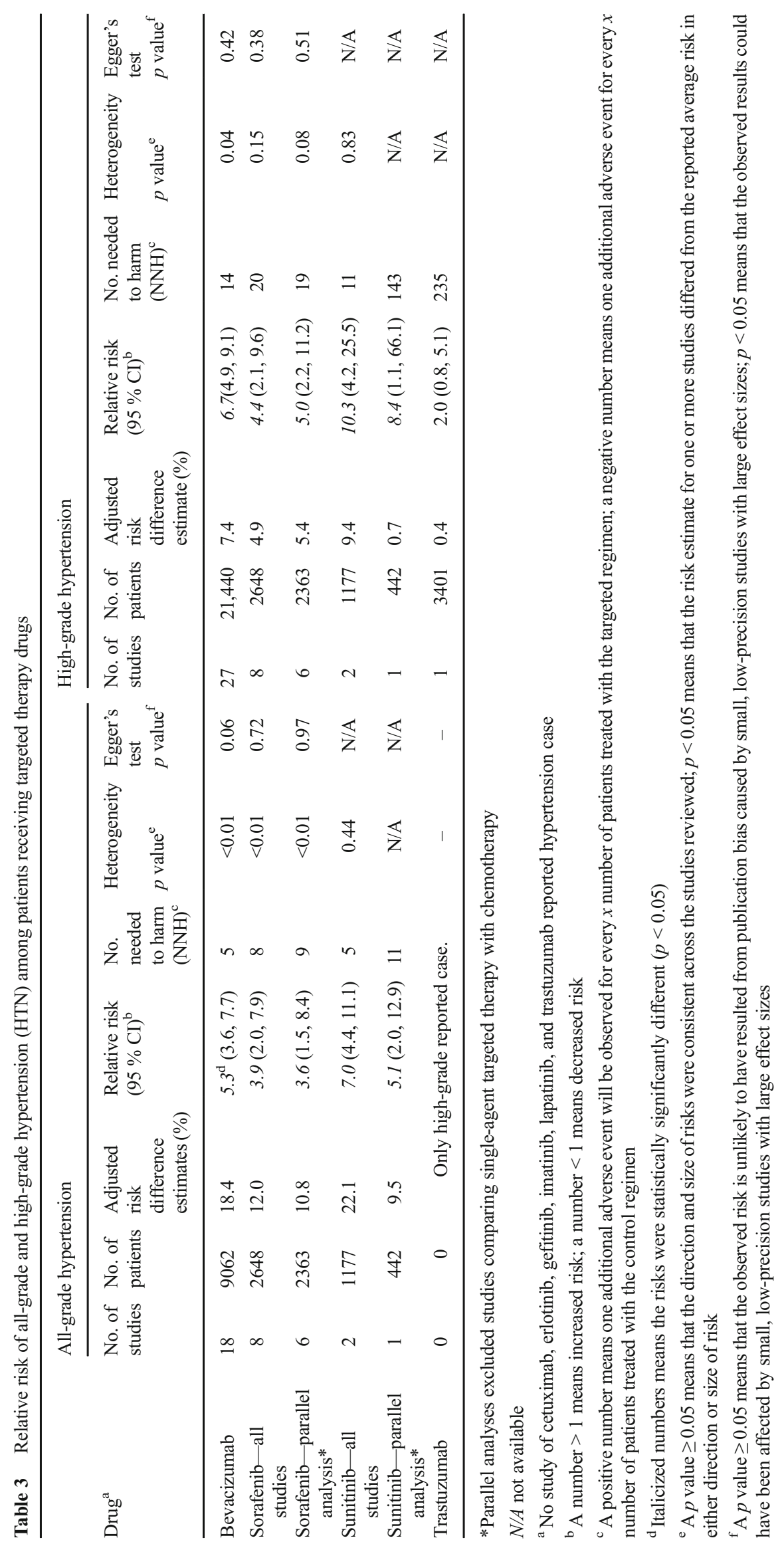




\section{Discussion}

Our findings indicate that several of the targeted agents are significantly associated with increased risk of particular cardiovascular toxicities. All-grade risk of cardiovascular toxicities for CHF (trastuzumab), DLVEF (sorafenib, sunitinib, trastuzumab), MI (sorafenib, based on one study of 92 patients), and HTN (bevacizumab, sorafenib, sunitinib) was significantly increased with specific targeted agents. In addition, high-grade risk of cardiovascular toxicities for CHF (trastuzumab), DLVEF (bevacizumab, trastuzumab), and HTN (bevacizumab, sorafenib, sunitinib) was significantly increased with certain targeted agents. Interestingly, the risk of all-grade or high-grade arrhythmia was not demonstrated for any of the studied targeted agents.
Further, the all-grade risk of MI was only noted for sorafenib based only on one study with no significant finding of any of the other targeted agents for high-risk of MI. The clinical significance of this finding is unknown.

Heterogeneity and Egger's test were completed. Abnormal findings include the heterogeneity $p$ value $(<0.01)$ (Egger's test was 0.65 ) for trastuzumab for all-grade DLVEF (Table 1); heterogeneity $p$ values $(<0.01)$ for all-grade HTN included bevacizumab, sorafenib-all studies and parallel analysis; Egger's tests were $0.06,0.72$, and 0.97 , respectively. The heterogeneity $p$ value was 0.04 (Egger's test was 0.42 ) for high-grade HTN for bevacizumab (Table 3). After reviewing probable studies associated with these findings, there are likely multiple factors associated including some with
Fig. 2 Relative risks of cardiovascular toxicities and $95 \%$ confidence limits. A relative risk $>1$ means risk of toxicity is higher with targeted therapy than with control therapy. A relative risk $<1$ means risk of toxicity is lower with targeted therapy than with control therapy. Asterisks $(*)$ indicate that relative risk with targeted therapy is significantly higher or lower than the control

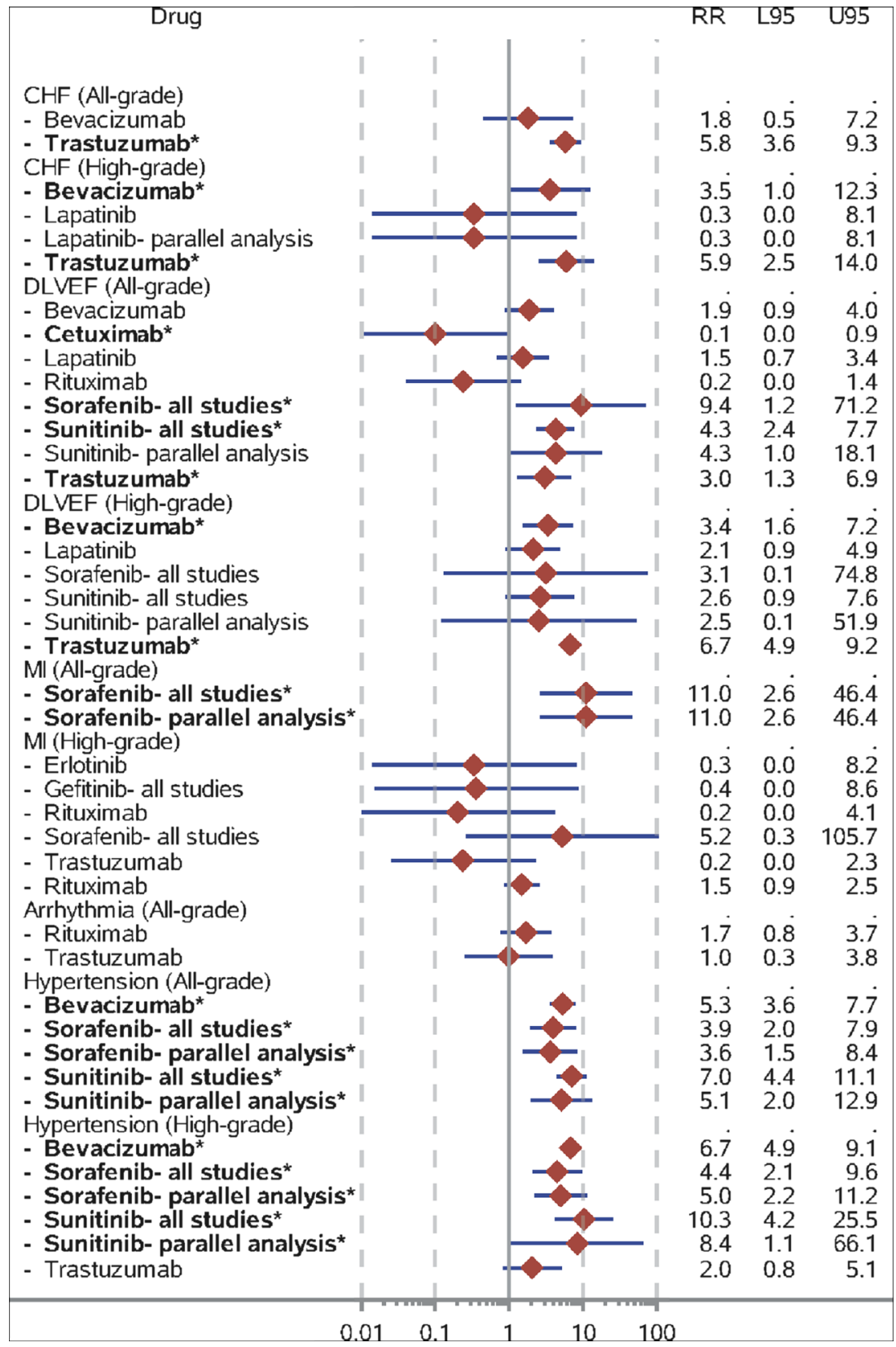


smaller sample sizes where it may have been difficult to see the effect and some were earlier studies where the effect may not have been as established and not as readily identified.

The incidence of these toxicities has been difficult to estimate. Many of these therapies are utilized for a short interval during a clinical trial whereas in routine clinical practice, a patient may be on these regimens for months and longer if they are responding to the treatment. In addition, patients with underlying comorbidities, especially those with cardiovascular risk factors, are often excluded from participating in clinical trials utilizing these agents. Further, subclinical cardiac adverse effects may not be noted and thus underestimations of cardiovascular toxicities may occur.

Other reports have noted variation in the incidence and clinical severity of CHF. A recent meta-analysis including almost 7000 patients treated with sunitinib revealed a rate of all-grade tyrosine kinase associated heart failure of $4.1 \%$ [146]. A metaanalysis based on five trials of 1497 patients studying trastuzumab-containing regimens found trastuzumab increased the risk of CHF [RR 3.49, $(1.88,6.47)$ moderate-quality evidence] and DLVEF [RR 2.65, $(1.48,4.74)]$ [147]. The findings of our study show a RR of $5.8(3.6,9.3)$ for all-grade and 5.9 $(2.5,14.0)$ for high-grade CHF, and a RR of $3.0(1.3,6.9)$ for allgrade DLVEF and $6.7(4.9,9.2)$ for high-grade DLVEF. Differences in methodology encompassing studies and agents included may attribute to some variation in results. Funakoshi et al. studied 4878 patients from 13 randomized trials. Highgrade HTN had a RR of 3.20 (2.19-4.68) compared to a RR of $4.4(2.1,9.6)$ for high-grade HTN in our study [148]. Another meta-analysis focusing on sorafenib noted a significantly increased risk of hypertension [RR 2.93; $(1.52,5.66)$; based on 16 studies] and DLVEF [RR 9.38; (1.24, 71.22); based on two studies]. Our findings for sorafenib showed a RR of 3.9 [(2.0, 7.9); based on eight studies] and a RR of DLVEF of 9.4 [(1.2, 71.2); based on one study] [149].

One study limitation is that only available agents approved by the FDA at the time of initiation were included. Since, more agents of this type have been approved by the FDA and are in use. However, we cannot infer from this study that they have similar risk to the agents we studied; for instance the risk of QT interval prolongation with vandetanib led the FDA in 2011 to implement a risk evaluation mitigation strategy program [150]. Another study limitation was that some agents had very few clinical trials performed prior to their FDA approval due to fast-tracking. This causes difficulty in assessing outcomes via meta-analysis when there are very few studies to base the results upon. For example, although sunitinib had only two studies during our review phase, it was included due to its significant use in clinical practice.

A third study limitation is that our findings were based on clinical trials adhering to strict inclusion/exclusion criteria and treatment algorithms. As these agents have been approved and released by the FDA, routine clinical practice may not include similar populations or adhere to regimented dosing criteria as performed in the clinical trials. Therefore, it may also be noted that documented cardiac events may differ in incidence and severity than those our meta-analysis is based upon.

Some of the endpoints noted may be a secondary endpoint rather than a primary endpoint. For example, targeted agent induced HTN may lead to myocardial ischemia and infarct rather than the agent directly attributing to the ischemic event [2]. We are not able to specifically determine whether some of the cardiovascular toxicities reported in the various studies are primary or secondary endpoints. However, if they are secondary endpoints, early identification and aggressive treatment of the primary endpoint, such as HTN, may limit or avoid a more significant secondary complication such as MI or CHF.

Recently, clinical experience in the use of some agents, such as trastuzimab, has demonstrated reversibility of CHF. In fact, many breast cancer patients have been rechallenged with trastuzimab following a DLVEF or CHF and have been able to continue on this targeted therapy for several years without recurrence of the toxicity [2]. We must always consider the risk/benefit ratio of utilizing cancer therapies such as these. Particularly in the setting of malignancy, close consideration should be made as to where the benefits of disease control justify the potential cardiovascular toxicities.

In conclusion, although targeted agents may be extremely beneficial in treating various malignancies, there are several with potential cardiovascular toxicities. Clinical experience has demonstrated that some may be transient and reversible and a careful risk/benefit analysis should be undertaken. These targeted therapies may be life-saving for the cancer population. Therefore, we recommend avid education for providers, patients and their families. Patients should be carefully screened prior to administration of agents with these possible effects and should be medically optimized prior to initiating treatment, especially those with significant cardiac disease. For example, patients should have normotensive blood pressure readings prior to initiation of targeted therapies with documented HTN toxicity. And, we promote frequent monitoring of patients on targeted therapies with known cardiovascular toxicity while on active treatment and posttreatment until the targeted therapy no longer may affect the cardiac status. This may allow patients the full benefit of these drugs in fighting their malignancy while potentially preventing cardiovascular complications. Finally, as noted in our results, not all cardiovascular toxicities are equal. Arrhythmia was not a toxicity of the targeted therapies studied and MI was noted as allgrade toxicity for only one of the drugs studied and based on a single small study so that this result should be interpreted judiciously. While CHF, DLVEF, and HTN were noted as all-grade and high-grade toxicities among several of the drugs. In addition, some of these toxicities may not be primary but a secondary toxicity. Further studies are necessary as newer agents in this class are approved and become common in the armamentarium of cancer treatment. 
Acknowledgments Dr. Elting is supported by grant RP140020, "Comparative Effectiveness Research on Cancer in Texas", from the Cancer Prevention and Research Institute of Texas.

\section{Compliance with ethical standards}

Conflict of interest I have no financial relationship with any organization that sponsored the research. I have full control of all primary data and will allow the journal to review the data if requested.

\section{Appendix}

Table 4 FDA-approved targeted therapies for cancer*

\begin{tabular}{ll}
\hline Drug name & Approved indication \\
\hline Alemtuzumab & B-cell CLL \\
Bevacizumab & Glioblastoma, NSCLC, met CRC, breast cancer \\
Bexarotene & CTCL \\
Bortezomib & Multiple myeloma, mantel call lymphoma \\
Cetuximab & CRC, SCCHN \\
Dasatinib & CML, ALL \\
Denileukin difitox & CTCL \\
Erlotinib & NSCLC, pancreatic cancer \\
Everolimus & Advanced RCC, subependymal giant cell \\
& astrocytoma, pancreatic neuroendocrine tumors \\
Gefitinib & NSCLC \\
Ibritumomab & NHL \\
Imatinib & GIST, leukemia \\
Lapatinib & advanced or metastatic breast cancer \\
Nilotinib & CML \\
Ofatumumab & CLL \\
Panitumumab & Met CRC \\
Pazopanib & Advanced RCC \\
Pralatrexate & Peripheral t-cell lymphoma \\
Rituximab & NHL \\
Romidepsin & CTCL \\
Sorafenib & Advanced RCC, hepatocellular carcinoma \\
Sunitinib & Met RCC, GIST \\
Temsirolimus & Advanced RCC \\
Tositumomab & NHL \\
Trastuzumab & Breast \\
Vorinostat & CTCL \\
\hline & \\
&
\end{tabular}

Source: Targeted Cancer Therapies-Fact Sheet. http://www.cancer. gov/cancertopics/factsheet/Therapy/targeted. Accessed November 2010

$A L L$ acute lymphoblastic leukemia, $A M L$ acute myeloid leukemia, $C M L$ chronic myelogenous leukemia, $C R C$ colorectal cancer, $C T C L$ cutaneous T cell lymphoma, GIST gastrointestinal stromal tumors, NHL nonHodgkin's lymphoma, $H N$ head and neck cancer, NSCLC non-small cell lung cancer, $R C C$ renal cell carcinoma, $S C C H N$ squamous cell carcinoma of the head and neck

*This is a list of targeted therapies that were approved by FDA in 2010 . However, there are other agents and indications being added to or removed from the list since then

\section{References}

1. Yusuf SW, Razeghi P, Yeh ET (2008) The diagnosis and management of cardiovascular disease in cancer patients. Curr Probl Cardiol 33(4):163-196. doi:10.1016/j.cpcardiol.2008.01.002

2. Ewer MS, Ewer SM (2015) Cardiotoxicity of anticancer treatments. Nat Rev Cardiol 12(11):620. doi:10.1038 /nrcardio.2015.133

3. Yeh ET, Tong AT, Lenihan DJ, Yusuf SW, Swafford J, Champion C, Durand JB, Gibbs H, Zafarmand AA, Ewer MS (2004) Cardiovascular complications of cancer therapy: diagnosis, pathogenesis, and management. Circulation 109(25):3122-3131. doi:10.1161/01.cir.0000133187.74800.b9

4. Ewer MS, Suter TM, Lenihan DJ, Niculescu L, Breazna A, Demetri GD, Motzer RJ (2014) Cardiovascular events among 1090 cancer patients treated with sunitinib, interferon, or placebo: a comprehensive adjudicated database analysis demonstrating clinically meaningful reversibility of cardiac events. Eur J Cancer 50(12):2162-2170. doi:10.1016/j.ejca.2014.05.013

5. National Cancer Institute (2010) Institute NC Targeted cancer therapies. Available at: http://www.cancer. gov/cancertopics/factsheet/Therapy/targeted. Accessed 09/10 $/ 2010$

6. Food and Drug Administration (2012) AstraZeneca Pharmaceuticals LP. Withdrawal of Approval of A New Drug Application for IRESSA. Available at: https://www. federalregister.gov/articles/2012/04/25/2012-9944/astrazenecapharmaceuticals-lp-withdrawal-of-approval-of-a-new-drugapplication-for-iressa\#page-24723. Accessed 09/10/2010

7. European Medicines Agency (2012) Iressa. 2009. Available from: http://www.ema.europa.eu/ema/indexjsp?curl= pages/medicines/human/medicines/001016/human med 000857 jsp\&mid=WC0b01ac058001d124. cited 6/15/2012 6/15/2012

8. Allegra CJ, Yothers G, O'Connell MJ, Sharif S, Colangelo LH, Lopa SH, Petrelli NJ, Goldberg RM, Atkins JN, Seay TE, Fehrenbacher L, O'Reilly S, Chu L, Azar CA, Wolmark N (2009) Initial safety report of NSABP C-08: a randomized phase III study of modified FOLFOX6 with or without bevacizumab for the adjuvant treatment of patients with stage II or III colon cancer. J Clin Oncol Off J Am Soc Clin Oncol 27(20):3385-3390. doi:10.1200/jco.2009.21.9220

9. Allegra CJ, Yothers G, O'Connell MJ, Sharif S, Petrelli NJ, Colangelo LH, Atkins JN, Seay TE, Fehrenbacher L, Goldberg RM, O'Reilly S, Chu L, Azar CA, Lopa S, Wolmark N (2011) Phase III trial assessing bevacizumab in stages II and III carcinoma of the colon: results of NSABP protocol C-08. J Clin Oncol Off J Am Soc Clin Oncol 29(1):11-16. doi:10.1200 /jco.2010.30.0855

10. Allegra CJ, Yothers G, O’Connell MJ, Sharif S, Petrelli NJ, Lopa SH, Wolmark N (2013) Bevacizumab in stage II-III colon cancer: 5 -year update of the National Surgical Adjuvant Breast and bowel project C-08 trial. J Clin Oncol Off J Am Soc Clin Oncol 31(3): 359-364. doi:10.1200/JCO.2012.44.4711

11. Baar J, Silverman P, Lyons J, Fu P, Abdul-Karim F, Ziats N, Wasman J, Hartman P, Jesberger J, Dumadag L, Hohler E, Leeming R, Shenk R, Chen H, McCrae K, Dowlati A, Remick SC, Overmoyer B (2009) A vasculature-targeting regimen of preoperative docetaxel with or without bevacizumab for locally advanced breast cancer: impact on angiogenic biomarkers. Clin Cancer Res 15(10):3583-3590. doi:10.1158/1078-0432.ccr-08-2917

12. Bear HD, Tang G, Rastogi P, Geyer CE Jr, Robidoux A, Atkins JN, Baez-Diaz L, Brufsky AM, Mehta RS, Fehrenbacher L, Young JA, Senecal FM, Gaur R, Margolese RG, Adams PT, Gross HM, Costantino JP, Swain SM, Mamounas EP, Wolmark N (2012) Bevacizumab added to neoadjuvant chemotherapy for 
breast cancer. N Eng1 J Med 366(4):310-320. doi:10.1056 /NEJMoa1111097

13. Bennouna J, Sastre J, Arnold D, Osterlund P, Greil R, Van Cutsem E, von Moos R, Vieitez JM, Bouche O, Borg C, Steffens CC, Alonso-Orduna V, Schlichting C, Reyes-Rivera I, Bendahmane B, Andre T, Kubicka S (2013) Continuation of bevacizumab after first progression in metastatic colorectal cancer (ML18147): a randomised phase 3 trial. Lancet Oncol 14(1):29-37. doi:10.1016/s1470-2045(12)70477-1

14. Boutsikou E, Kontakiotis T, Zarogoulidis P, Darwiche K, Eleptheriadou E, Porpodis K, Galaktidou G, Sakkas L, Hohenforst-Schmidt W, Tsakiridis K, Karaiskos T, Zarogoulidis K (2013) Docetaxel-carboplatin in combination with erlotinib and/or bevacizumab in patients with non-small cell lung cancer. Onco Targets Ther 6:125-134. doi:10.2147/ott.s42245

15. Brufsky AM, Hurvitz S, Perez E, Swamy R, Valero V, O'Neill V, Rugo HS (2011) RIBBON-2: a randomized, double-blind, placebo-controlled, phase III trial evaluating the efficacy and safety of bevacizumab in combination with chemotherapy for second-line treatment of human epidermal growth factor receptor 2-negative metastatic breast cancer. J Clin Oncol Off J Am Soc Clin Oncol 29(32):4286-4293. doi:10.1200/jco.2010.34.1255

16. Cameron D, Brown J, Dent R, Jackisch C, Mackey J, Pivot X, Steger GG, Suter TM, Toi M, Parmar M, Laeufle R, Im YH, Romieu G, Harvey V, Lipatov O, Pienkowski T, Cottu P, Chan A, Im SA, Hall PS, Bubuteishvili-Pacaud L, Henschel V, Deurloo RJ, Pallaud C, Bell R (2013) Adjuvant bevacizumab-containing therapy in triple-negative breast cancer (BEATRICE): primary results of a randomised, phase 3 trial. Lancet Oncol 14(10):933942. doi:10.1016/s1470-2045(13)70335-8

17. Cassidy J, Clarke S, Diaz-Rubio E, Scheithauer W, Figer A, Wong R, Koski S, Rittweger K, Gilberg F, Saltz L (2011) XELOX vs FOLFOX-4 as first-line therapy for metastatic colorectal cancer: NO16966 updated results. Br J Cancer 105(1):58-64. doi:10.1038 /bjc.2011.201

18. de Gramont A, Van Cutsem E, Schmoll HJ, Tabernero J, Clarke S, Moore MJ, Cunningham D, Cartwright TH, Hecht JR, Rivera F, Im SA, Bodoky G, Salazar R, Maindrault-Goebel F, ShachamShmueli E, Bajetta E, Makrutzki M, Shang A, Andre T, Hoff PM (2012) Bevacizumab plus oxaliplatin-based chemotherapy as adjuvant treatment for colon cancer (AVANT): a phase 3 randomised controlled trial. Lancet Oncol 13(12):1225-1233. doi:10.1016/s1470-2045(12)70509-0

19. Fuchs CS, Marshall J, Mitchell E, Wierzbicki R, Ganju V, Jeffery M, Schulz J, Richards D, Soufi-Mahjoubi R, Wang B, Barrueco J (2007) Randomized, controlled trial of irinotecan plus infusional, bolus, or oral fluoropyrimidines in first-line treatment of metastatic colorectal cancer: results from the BICC-C study. J Clin Oncol Off J Am Soc Clin Oncol 25(30):4779-4786. doi:10.1200 /jco.2007.11.3357

20. Giantonio BJ, Catalano PJ, Meropol NJ, O’Dwyer PJ, Mitchell EP, Alberts SR, Schwartz MA, Benson AB 3rd, Eastern Cooperative Oncology Group Study E (2007) Bevacizumab in combination with oxaliplatin, fluorouracil, and leucovorin (FOLFOX4) for previously treated metastatic colorectal cancer: results from the eastern cooperative oncology group study E3200. J Clin Oncol 25(12):1539-1544. doi:10.1200 /JCO.2006.09.6305

21. Guan ZZ, Xu JM, Luo RC, Feng FY, Wang LW, Shen L, Yu SY, Ba Y, Liang J, Wang D, Qin SK, Wang JJ, He J, Qi C, Xu RH (2011) Efficacy and safety of bevacizumab plus chemotherapy in Chinese patients with metastatic colorectal cancer: a randomized phase III ARTIST trial. Chin J Cancer 30(10):682-689. doi:10.5732/cjc.011.10188

22. Herbst RS, O'Neill VJ, Fehrenbacher L, Belani CP, Bonomi PD, Hart L, Melnyk O, Ramies D, Lin M, Sandler A (2007) Phase II study of efficacy and safety of bevacizumab in combination with chemotherapy or erlotinib compared with chemotherapy alone for treatment of recurrent or refractory non small-cell lung cancer. J Clin Oncol Off J Am Soc Clin Oncol 25(30):4743-4750. doi:10.1200/jco.2007.12.3026

23. Hochster HS, Hart LL, Ramanathan RK, Childs BH, Hainsworth JD, Cohn AL, Wong L, Fehrenbacher L, Abubakr Y, Saif MW, Schwartzberg L, Hedrick E (2008) Safety and efficacy of oxaliplatin and fluoropyrimidine regimens with or without bevacizumab as first-line treatment of metastatic colorectal cancer: results of the TREE study. J Clin Oncol Off J Am Soc Clin Oncol 26(21):3523-3529. doi:10.1200/jco.2007.15.4138

24. Hurwitz H, Fehrenbacher L, Novotny W, Cartwright T, Hainsworth J, Heim W, Berlin J, Baron A, Griffing S, Holmgren E, Ferrara N, Fyfe G, Rogers B, Ross R, Kabbinavar F (2004) Bevacizumab plus irinotecan, fluorouracil, and leucovorin for metastatic colorectal cancer. N Engl J Med 350(23):2335-2342. doi:10.1056/NEJMoa032691

25. Hurwitz HI, Fehrenbacher L, Hainsworth JD, Heim W, Berlin J, Holmgren E, Hambleton J, Novotny WF, Kabbinavar F (2005) Bevacizumab in combination with fluorouracil and leucovorin: an active regimen for first-line metastatic colorectal cancer. J Clin Oncol Off J Am Soc Clin Oncol 23(15):3502-3508. doi:10.1200/jco.2005.10.017

26. Johnson DH, Fehrenbacher L, Novotny WF, Herbst RS, Nemunaitis JJ, Jablons DM, Langer CJ, DeVore RF 3rd, Gaudreault J, Damico LA, Holmgren E, Kabbinavar F (2004) Randomized phase II trial comparing bevacizumab plus carboplatin and paclitaxel with carboplatin and paclitaxel alone in previously untreated locally advanced or metastatic non-smallcell lung cancer. J Clin Oncol Off J Am Soc Clin Oncol 22(11): 2184-2191. doi:10.1200/jco.2004.11.022

27. Kabbinavar F, Hurwitz HI, Fehrenbacher L, Meropol NJ, Novotny WF, Lieberman G, Griffing S, Bergsland E (2003) Phase II, randomized trial comparing bevacizumab plus fluorouracil (FU)/ leucovorin (LV) with FU/LV alone in patients with metastatic colorectal cancer. J Clin Oncol Off J Am Soc Clin Oncol 21(1):60 65

28. Kabbinavar FF, Schulz J, McCleod M, Patel T, Hamm JT, Hecht JR, Mass R, Perrou B, Nelson B, Novotny WF (2005) Addition of bevacizumab to bolus fluorouracil and leucovorin in first-line metastatic colorectal cancer: results of a randomized phase II trial. J Clin Oncol Off J Am Soc Clin Oncol 23(16):3697-3705. doi:10.1200/jco.2005.05.112

29. Kemeny NE, Jarnagin WR, Capanu M, Fong Y, Gewirtz AN, Dematteo RP, D'Angelica MI (2011) Randomized phase II trial of adjuvant hepatic arterial infusion and systemic chemotherapy with or without bevacizumab in patients with resected hepatic metastases from colorectal cancer. J Clin Oncol Off J Am Soc Clin Oncol 29(7):884-889. doi:10.1200/jco.2010.32.5977

30. Martin M, Roche H, Pinter T, Crown J, Kennedy MJ, Provencher L, Priou F, Eiermann W, Adrover E, Lang I, Ramos M, Latreille J, Jagiello-Gruszfeld A, Pienkowski T, Alba E, Snyder R, Almel S, Rolski J, Munoz M, Moroose R, Hurvitz S, Banos A, Adewoye H, Hei YJ, Lindsay MA, Rupin M, Cabaribere D, Lemmerick Y, Mackey JR, investigators T (2011) Motesanib, or open-label bevacizumab, in combination with paclitaxel, as first-line treatment for HER2-negative locally recurrent or metastatic breast cancer: a phase 2, randomised, double-blind, placebo-controlled study. Lancet Oncol 12(4):369-376. doi:10.1016/S1470-2045(11 )70037-7

31. Miles DW, Chan A, Dirix LY, Cortes J, Pivot X, Tomczak P, Delozier T, Sohn JH, Provencher L, Puglisi F, Harbeck N, Steger GG, Schneeweiss A, Wardley AM, Chlistalla A, Romieu G (2010) Phase III study of bevacizumab plus docetaxel compared with placebo plus docetaxel for the first-line treatment of human 
epidermal growth factor receptor 2-negative metastatic breast cancer. J Clin Oncol Off J Am Soc Clin Oncol 28(20):3239-3247. doi:10.1200/jco.2008.21.6457

32. Miller KD, Chap LI, Holmes FA, Cobleigh MA, Marcom PK, Fehrenbacher L, Dickler M, Overmoyer BA, Reimann JD, Sing AP, Langmuir V, Rugo HS (2005) Randomized phase III trial of capecitabine compared with bevacizumab plus capecitabine in patients with previously treated metastatic breast cancer. J Clin Oncol Off J Am Soc Clin Oncol 23(4):792-799. doi:10.1200 /jco.2005.05.098

33. Miller K, Wang M, Gralow J, Dickler M, Cobleigh M, Perez EA, Shenkier T, Cella D, Davidson NE (2007) Paclitaxel plus bevacizumab versus paclitaxel alone for metastatic breast cancer. N Engl J Med 357(26):2666-2676. doi:10.1056/NEJMoa072113

34. Moehler M, Sprinzl MF, Abdelfattah M, Schimanski CC, Adami B, Godderz W, Majer K, Flieger D, Teufel A, Siebler J, Hoehler T, Galle PR, Kanzler S (2009) Capecitabine and irinotecan with and without bevacizumab for advanced colorectal cancer patients. World J Gastroenterol 15(4):449-456

35. Niho S, Kunitoh H, Nokihara H, Horai T, Ichinose Y, Hida T, Yamamoto N, Kawahara M, Shinkai T, Nakagawa K, Matsui K, Negoro S, Yokoyama A, Kudoh S, Kiura K, Mori K, Okamoto H, Sakai H, Takeda K, Yokota S, Saijo N, Fukuoka M, Group JOS (2012) Randomized phase II study of first-line carboplatin-paclitaxel with or without bevacizumab in Japanese patients with advanced non-squamous non-small-cell lung cancer. Lung Cancer 76(3):362-367. doi:10.1016/j.lungcan.2011.12.005

36. Reck M, von Pawel J, Zatloukal P, Ramlau R, Gorbounova V, Hirsh V, Leighl N, Mezger J, Archer V, Moore N, Manegold C (2009) Phase III trial of cisplatin plus gemcitabine with either placebo or bevacizumab as first-line therapy for nonsquamous non-small-cell lung cancer: AVAil. J Clin Oncol Off J Am Soc Clin Oncol 27(8):1227-1234. doi:10.1200/jco.2007.14.5466

37. Robert NJ, Dieras V, Glaspy J, Brufsky AM, Bondarenko I, Lipatov ON, Perez EA, Yardley DA, Chan SY, Zhou X, Phan SC, O'Shaughnessy J (2011) RIBBON-1: randomized, doubleblind, placebo-controlled, phase III trial of chemotherapy with or without bevacizumab for first-line treatment of human epidermal growth factor receptor 2-negative, locally recurrent or metastatic breast cancer. J Clin Oncol Off J Am Soc Clin Oncol 29(10): 1252-1260. doi:10.1200/jco.2010.28.0982

38. Saltz LB, Clarke S, Diaz-Rubio E, Scheithauer W, Figer A, Wong R, Koski S, Lichinitser M, Yang TS, Rivera F, Couture F, Sirzen F, Cassidy J (2008) Bevacizumab in combination with oxaliplatinbased chemotherapy as first-line therapy in metastatic colorectal cancer: a randomized phase III study. J Clin Oncol Off J Am Soc Clin Oncol 26(12):2013-2019. doi:10.1200/jco.2007.14.9930

39. Sandler A, Gray R, Perry MC, Brahmer J, Schiller JH, Dowlati A, Lilenbaum R, Johnson DH (2006) Paclitaxel-carboplatin alone or with bevacizumab for non-small-cell lung cancer. N Engl J Med 355(24):2542-2550. doi:10.1056/NEJMoa061884

40. Stathopoulos GP, Batziou C, Trafalis D, Koutantos J, Batzios S, Stathopoulos J, Legakis J, Armakolas A (2010) Treatment of colorectal cancer with and without bevacizumab: a phase III study. Oncology 78(5-6):376-381. doi:10.1159/000320520

41. Tebbutt NC, Wilson K, Gebski VJ, Cummins MM, Zannino D, van Hazel GA, Robinson B, Broad A, Ganju V, Ackland SP, Forgeson G, Cunningham D, Saunders MP, Stockler MR, Chua Y, Zalcberg JR, Simes RJ, Price TJ (2010) Capecitabine, bevacizumab, and mitomycin in first-line treatment of metastatic colorectal cancer: results of the Australasian Gastrointestinal Trials Group Randomized Phase III MAX Study. J Clin Oncol Off J Am Soc Clin Oncol 28(19):3191-3198. doi:10.1200 jjco.2009.27.7723

42. von Minckwitz G, Eidtmann H, Rezai M, Fasching PA, Tesch H, Eggemann H, Schrader I, Kittel K, Hanusch C, Kreienberg R,
Solbach C, Gerber B, Jackisch C, Kunz G, Blohmer JU, Huober J, Hauschild M, Fehm T, Muller BM, Denkert C, Loibl S, Nekljudova V, Untch M, German Breast G, Arbeitsgemeinschaft Gynakologische Onkologie-Breast Study G (2012) Neoadjuvant chemotherapy and bevacizumab for HER2-negative breast cancer. N Engl J Med 366(4):299-309. doi:10.1056/NEJMoa1111065

43. Bokemeyer C, Bondarenko I, Makhson A, Hartmann JT, Aparicio J, de Braud F, Donea S, Ludwig H, Schuch G, Stroh C, Loos AH, Zubel A, Koralewski P (2009) Fluorouracil, leucovorin, and oxaliplatin with and without cetuximab in the first-line treatment of metastatic colorectal cancer. J Clin Oncol Off J Am Soc Clin Oncol 27(5):663-671. doi:10.1200/jco.2008.20.8397

44. Borner M, Koeberle D, Von Moos R, Saletti P, Rauch D, Hess V, Trojan A, Helbling D, Pestalozzi B, Caspar C, Ruhstaller T, Roth A, Kappeler A, Dietrich D, Lanz D, Mingrone W, Swiss Group for Clinical Cancer Research BS (2008) Adding cetuximab to capecitabine plus oxaliplatin (XELOX) in first-line treatment of metastatic colorectal cancer: a randomized phase II trial of the Swiss Group for Clinical Cancer Research SAKK. Ann Oncol 19(7): 1288-1292. doi:10.1093/annonc/mdn058

45. Fleming MT, Sonpavde G, Kolodziej M, Awasthi S, Hutson TE, Martincic D, Rastogi A, Rousey SR, Weinstein RE, Galsky MD, Berry WR, Wang Y, Boehm KA, Asmar L, Rauch MA, Beer TM (2012) Association of rash with outcomes in a randomized phase II trial evaluating cetuximab in combination with mitoxantrone plus prednisone after docetaxel for metastatic castration-resistant prostate cancer. Clin Genitourin Cancer 10(1):6-14. doi:10.1016 /j.clgc.2011.11.003

46. Van Cutsem E, Kohne CH, Hitre E, Zaluski J, Chang Chien CR, Makhson A, D'Haens G, Pinter T, Lim R, Bodoky G, Roh JK, Folprecht G, Ruff P, Stroh C, Tejpar S, Schlichting M, Nippgen J, Rougier P (2009) Cetuximab and chemotherapy as initial treatment for metastatic colorectal cancer. N Engl J Med 360(14): 1408-1417. doi:10.1056/NEJMoa0805019

47. Vermorken JB, Mesia R, Rivera F, Remenar E, Kawecki A, Rottey S, Erfan J, Zabolotnyy D, Kienzer HR, Cupissol D, Peyrade F, Benasso M, Vynnychenko I, De Raucourt D, Bokemeyer C, Schueler A, Amellal N, Hitt R (2008) Platinum-based chemotherapy plus cetuximab in head and neck cancer. N Engl J Med 359(11):1116-1127. doi:10.1056/NEJMoa0802656

48. Bylicki O, Ferlay C, Chouaid C, Lavole A, Barlesi F, Dubos C, Westeel V, Crequit J, Corre R, Vergnenegre A, Monnet I, Le Caer H, Fournel P, Vaylet F, Falchero L, Poudenx M, Linard P, Perol D, Zalcman G, Perol M (2013) Efficacy of pemetrexed as second-line therapy in advanced NSCLC after either treatment-free interval or maintenance therapy with gemcitabine or erlotinib in IFCT-GFPC 05-02 phase III study. J Thorac Oncol 8(7):906-914. doi:10.1097 /JTO.0b013e31828cb505

49. Cappuzzo F, Ciuleanu T, Stelmakh L, Cicenas S, Szczesna A, Juhasz E, Esteban E, Molinier O, Brugger W, Melezinek I, Klingelschmitt G, Klughammer B, Giaccone G (2010) Erlotinib as maintenance treatment in advanced non-small-cell lung cancer: a multicentre, randomised, placebo-controlled phase 3 study. Lancet Oncol 11(6):521-529. doi:10.1016/s1470-2045(10 )70112-1

50. Coudert B, Ciuleanu T, Park K, Wu YL, Giaccone G, Brugger W, Gopalakrishna P, Cappuzzo F, Investigators S (2012) Survival benefit with erlotinib maintenance therapy in patients with advanced non-small-cell lung cancer (NSCLC) according to response to first-line chemotherapy. Ann Oncol 23(2):388-394. doi:10.1093/annonc/mdr125

51. Gatzemeier U, Pluzanska A, Szczesna A, Kaukel E, Roubec J, De Rosa F, Milanowski J, Karnicka-Mlodkowski H, Pesek M, Serwatowski P, Ramlau R, Janaskova T, Vansteenkiste J, Strausz J, Manikhas GM, Von Pawel J (2007) Phase III study of erlotinib in combination with cisplatin and gemcitabine in advanced non- 
small-cell lung cancer: the Tarceva Lung Cancer Investigation Trial. J Clin Oncol Off J Am Soc Clin Oncol 25(12):1545-1552. doi:10.1200/jco.2005.05.1474

52. Herbst RS, Prager D, Hermann R, Fehrenbacher L, Johnson BE, Sandler A, Kris MG, Tran HT, Klein P, Li X, Ramies D, Johnson DH, Miller VA, Group TI (2005) TRIBUTE: a phase III trial of erlotinib hydrochloride (OSI-774) combined with carboplatin and paclitaxel chemotherapy in advanced non-small-cell lung cancer. J Clin Oncol 23(25):5892-5899. doi:10.1200/JCO.2005.02.840

53. Lilenbaum R, Axelrod R, Thomas S, Dowlati A, Seigel L, Albert D, Witt K, Botkin D (2008) Randomized phase II trial of erlotinib or standard chemotherapy in patients with advanced non-smallcell lung cancer and a performance status of 2. J Clin Oncol Off J Am Soc Clin Oncol 26(6):863-869. doi:10.1200 /jco.2007.13.2720

54. Mok TS, Wu YL, Yu CJ, Zhou C, Chen YM, Zhang L, Ignacio J, Liao M, Srimuninnimit V, Boyer MJ, Chua-Tan M, Sriuranpong V, Sudoyo AW, Jin K, Johnston M, Chui W, Lee JS (2009) Randomized, placebo-controlled, phase II study of sequential erlotinib and chemotherapy as first-line treatment for advanced nonsmall-cell lung cancer. J Clin Oncol Off J Am Soc Clin Oncol 27(30):5080-5087. doi:10.1200/jco.2008.21.5541

55. Moore MJ, Goldstein D, Hamm J, Figer A, Hecht JR, Gallinger S, Au HJ, Murawa P, Walde D, Wolff RA, Campos D, Lim R, Ding K, Clark G, Voskoglou-Nomikos T, Ptasynski M, Parulekar W, National Cancer Institute of Canada Clinical Trials G (2007) Erlotinib plus gemcitabine compared with gemcitabine alone in patients with advanced pancreatic cancer: a phase III trial of the National Cancer Institute of Canada Clinical Trials Group. J Clin Oncol 25(15):1960-1966. doi:10.1200/JCO.2006.07.9525

56. Perol M, Chouaid C, Perol D, Barlesi F, Gervais R, Westeel V, Crequit J, Lena H, Vergnenegre A, Zalcman G, Monnet I, Le Caer H, Fournel P, Falchero L, Poudenx M, Vaylet F, Segura-Ferlay C, Devouassoux-Shisheboran M, Taron M, Milleron B (2012) Randomized, phase III study of gemcitabine or erlotinib maintenance therapy versus observation, with predefined second-line treatment, after cisplatin-gemcitabine induction chemotherapy in advanced non-small-cell lung cancer. J Clin Oncol Off J Am Soc Clin Oncol 30(28):3516-3524. doi:10.1200/jco.2011.39.9782

57. Shepherd FA, Rodrigues Pereira J, Ciuleanu T, Tan EH, Hirsh V, Thongprasert S, Campos D, Maoleekoonpiroj S, Smylie M, Martins R, van Kooten M, Dediu M, Findlay B, Tu D, Johnston D, Bezjak A, Clark G, Santabarbara P, Seymour L, National Cancer Institute of Canada Clinical Trials G (2005) Erlotinib in previously treated non-small-cell lung cancer. N Engl J Med 353(2):123-132. doi:10.1056/NEJMoa050753

58. Vickers MM, Powell ED, Asmis TR, Jonker DJ, Hilton JF, O'Callaghan CJ, Tu D, Parulekar W, Moore MJ (2012) Comorbidity, age and overall survival in patients with advanced pancreatic cancer-results from NCIC CTG PA.3: a phase III trial of gemcitabine plus erlotinib or placebo. Eur J Cancer 48(10): 1434-1442. doi:10.1016/j.ejca.2011.10.035

59. Crino L, Cappuzzo F, Zatloukal P, Reck M, Pesek M, Thompson JC, Ford HE, Hirsch FR, Varella-Garcia M, Ghiorghiu S, Duffield EL, Armour AA, Speake G, Cullen M (2008) Gefitinib versus vinorelbine in chemotherapy-naive elderly patients with advanced non-small-cell lung cancer (INVITE): a randomized, phase II study. J Clin Oncol Off J Am Soc Clin Oncol 26(26):42534260. doi:10.1200/jco.2007.15.0672

60. Cufer T, Vrdoljak E, Gaafar R, Erensoy I, Pemberton K, Group SS (2006) Phase II, open-label, randomized study (SIGN) of singleagent gefitinib (IRESSA) or docetaxel as second-line therapy in patients with advanced (stage IIIb or IV) non-small-cell lung cancer. Anti-Cancer Drugs 17(4):401-409. doi:10.1097/01. cad.0000203381.99490.ab
61. Gaafar RM, Surmont VF, Scagliotti GV, Van Klaveren RJ, Papamichael D, Welch JJ, Hasan B, Torri V, van Meerbeeck JP, Group ELC, the Italian Lung Cancer P (2011) A double-blind, randomised, placebo-controlled phase III intergroup study of gefitinib in patients with advanced NSCLC, non-progressing after first line platinum-based chemotherapy (EORTC 08021/ILCP 01/ 03). Eur J Cancer 47(15):2331-2340. doi:10.1016/j. ejca.2011.06.045

62. Giaccone G, Herbst RS, Manegold C, Scagliotti G, Rosell R, Miller V, Natale RB, Schiller JH, Von Pawel J, Pluzanska A, Gatzemeier U, Grous J, Ochs JS, Averbuch SD, Wolf MK, Rennie P, Fandi A, Johnson DH (2004) Gefitinib in combination with gemcitabine and cisplatin in advanced non-small-cell lung cancer: a phase III trial-INTACT 1. J Clin Oncol Off J Am Soc Clin Oncol 22(5):777-784. doi:10.1200/jco.2004.08.001

63. Goss G, Ferry D, Wierzbicki R, Laurie SA, Thompson J, Biesma B, Hirsch FR, Varella-Garcia M, Duffield E, Ataman OU, Zarenda M, Armour AA (2009) Randomized phase II study of gefitinib compared with placebo in chemotherapy-naive patients with advanced non-small-cell lung cancer and poor performance status. J Clin Oncol Off J Am Soc Clin Oncol 27(13):2253-2260. doi:10.1200/jco.2008.18.4408

64. Herbst RS, Giaccone G, Schiller JH, Natale RB, Miller V, Manegold C, Scagliotti G, Rosell R, Oliff I, Reeves JA, Wolf MK, Krebs AD, Averbuch SD, Ochs JS, Grous J, Fandi A, Johnson DH (2004) Gefitinib in combination with paclitaxel and carboplatin in advanced non-small-cell lung cancer: a phase III trial-INTACT 2. J Clin Oncol Off J Am Soc Clin Oncol 22(5): 785-794. doi:10.1200/jco.2004.07.215

65. Kelly K, Chansky K, Gaspar LE, Albain KS, Jett J, Ung YC, Lau DH, Crowley JJ, Gandara DR (2008) Phase III trial of maintenance gefitinib or placebo after concurrent chemoradiotherapy and docetaxel consolidation in inoperable stage III non-smallcell lung cancer: SWOG S0023. J Clin Oncol Off J Am Soc Clin Oncol 26(15):2450-2456. doi:10.1200/jco.2007.14.4824

66. Kim ES, Hirsh V, Mok T, Socinski MA, Gervais R, Wu YL, Li LY, Watkins CL, Sellers MV, Lowe ES, Sun Y, Liao ML, Osterlind K, Reck M, Armour AA, Shepherd FA, Lippman SM, Douillard JY (2008) Gefitinib versus docetaxel in previously treated non-smallcell lung cancer (INTEREST): a randomised phase III trial. Lancet 372(9652):1809-1818. doi:10.1016/s0140-6736(08)61758-4

67. Lee DH, Park K, Kim JH, Lee JS, Shin SW, Kang JH, Ahn MJ, Ahn JS, Suh C, Kim SW (2010) Randomized phase III trial of gefitinib versus docetaxel in non-small cell lung cancer patients who have previously received platinum-based chemotherapy. Clin Cancer Res 16(4):1307-1314. doi:10.1158/1078-0432.ccr-091903

68. Maemondo M, Inoue A, Kobayashi K, Sugawara S, Oizumi S, Isobe $\mathrm{H}$, Gemma A, Harada M, Yoshizawa H, Kinoshita I, Fujita Y, Okinaga S, Hirano H, Yoshimori K, Harada T, Ogura T, Ando M, Miyazawa H, Tanaka T, Saijo Y, Hagiwara K, Morita S, Nukiwa T, North-East Japan Study G (2010) Gefitinib or chemotherapy for non-small-cell lung cancer with mutated EGFR. N Engl J Med 362(25):2380-2388. doi:10.1056/NEJMoa0909530

69. Maruyama R, Nishiwaki Y, Tamura T, Yamamoto N, Tsuboi M, Nakagawa K, Shinkai T, Negoro S, Imamura F, Eguchi K, Takeda $\mathrm{K}$, Inoue $\mathrm{A}$, Tomii $\mathrm{K}$, Harada $\mathrm{M}$, Masuda $\mathrm{N}$, Jiang $\mathrm{H}$, Itoh $\mathrm{Y}$, Ichinose Y, Saijo N, Fukuoka M (2008) Phase III study, V-1532 , of gefitinib versus docetaxel in previously treated Japanese patients with non-small-cell lung cancer. J Clin Oncol Off J Am Soc Clin Oncol 26(26):4244-4252. doi:10.1200 jjco.2007.15.0185

70. Mitsudomi T, Morita S, Yatabe Y, Negoro S, Okamoto I, Tsurutani J, Seto T, Satouchi M, Tada H, Hirashima T, Asami K, Katakami N, Takada M, Yoshioka H, Shibata K, Kudoh S, Shimizu E, Saito H, Toyooka S, Nakagawa K, Fukuoka M, West Japan Oncology G 
(2010) Gefitinib versus cisplatin plus docetaxel in patients with non-small-cell lung cancer harbouring mutations of the epidermal growth factor receptor (WJTOG3405): an open label, randomised phase 3 trial. Lancet Oncol 11(2):121-128. doi:10.1016/S14702045(09)70364-X

71. Mok TS, Wu YL, Thongprasert S, Yang CH, Chu DT, Saijo N, Sunpaweravong P, Han B, Margono B, Ichinose Y, Nishiwaki Y, Ohe Y, Yang JJ, Chewaskulyong B, Jiang H, Duffield EL, Watkins CL, Armour AA, Fukuoka M (2009) Gefitinib or carboplatinpaclitaxel in pulmonary adenocarcinoma. N Engl J Med 361(10):947-957. doi:10.1056/NEJMoa0810699

72. Morere JF, Brechot JM, Westeel V, Gounant V, Lebeau B, Vaylet F, Barlesi F, Urban T, Souquet PJ, Debieuvre D, Baudrin L, Zalcman G, Morin F, Milleron B, Moro-Sibilot D (2010) Randomized phase II trial of gefitinib or gemcitabine or docetaxel chemotherapy in patients with advanced non-small-cell lung cancer and a performance status of 2 or 3 (IFCT-0301 study). Lung Cancer 70(3):301-307. doi:10.1016/j.lungcan.2010.03.003

73. Takeda K, Hida T, Sato T, Ando M, Seto T, Satouchi M, Ichinose Y, Katakami N, Yamamoto N, Kudoh S, Sasaki J, Matsui K, Takayama K, Kashii T, Iwamoto Y, Sawa T, Okamoto I, Kurata T, Nakagawa K, Fukuoka M (2010) Randomized phase III trial of platinum-doublet chemotherapy followed by gefitinib compared with continued platinum-doublet chemotherapy in Japanese patients with advanced non-small-cell lung cancer: results of a West Japan thoracic oncology group trial (WJTOG0203). J Clin Oncol Off J Am Soc Clin Oncol 28(5):753-760. doi:10.1200 /jco.2009.23.3445

74. Thatcher N, Chang A, Parikh P, Rodrigues Pereira J, Ciuleanu T, von Pawel J, Thongprasert S, Tan EH, Pemberton K, Archer V, Carroll K (2005) Gefitinib plus best supportive care in previously treated patients with refractory advanced non-small-cell lung cancer: results from a randomised, placebo-controlled, multicentre study (iressa survival evaluation in lung cancer). Lancet 366(9496):1527-1537. doi:10.1016/s0140-6736(05)67625-8

75. Tsuboi M, Kato H, Nagai K, Tsuchiya R, Wada H, Tada H, Ichinose Y, Fukuoka M, Jiang H (2005) Gefitinib in the adjuvant setting: safety results from a phase III study in patients with completely resected non-small cell lung cancer. Anti-Cancer Drugs 16(10):1123-1128

76. Zhang L, Ma S, Song X, Han B, Cheng Y, Huang C, Yang S, Liu X, Liu Y, Lu S, Wang J, Zhang S, Zhou C, Zhang X, Hayashi N, Wang M, investigators I (2012) Gefitinib versus placebo as maintenance therapy in patients with locally advanced or metastatic non-small-cell lung cancer (INFORM; C-TONG 0804): a multicentre, double-blind randomised phase 3 trial. Lancet Oncol 13(5):466-475. doi:10.1016/S1470-2045(12)70117-1

77. Biondi A, Schrappe M, De Lorenzo P, Castor A, Lucchini G, Gandemer V, Pieters R, Stary J, Escherich G, Campbell M, Li CK, Vora A, Arico M, Rottgers S, Saha V, Valsecchi MG (2012) Imatinib after induction for treatment of children and adolescents with Philadelphia-chromosome-positive acute lymphoblastic leukaemia (EsPhALL): a randomised, open-label, intergroup study. Lancet Oncol 13(9):936-945. doi:10.1016/s1470-2045(12 )70377-7

78. Dematteo RP, Ballman KV, Antonescu CR, Maki RG, Pisters PW, Demetri GD, Blackstein ME, Blanke CD, von Mehren M, Brennan MF, Patel S, McCarter MD, Polikoff JA, Tan BR, Owzar K, American College of Surgeons Oncology Group Intergroup Adjuvant GST (2009) Adjuvant imatinib mesylate after resection of localised, primary gastrointestinal stromal tumour: a randomised, double-blind, placebo-controlled trial. Lancet 373(9669):1097-1104. doi:10.1016/S0140-6736(09)60500-6

79. Druker BJ, Guilhot F, O'Brien SG, Gathmann I, Kantarjian H, Gattermann N, Deininger MW, Silver RT, Goldman JM, Stone RM, Cervantes F, Hochhaus A, Powell BL, Gabrilove JL,
Rousselot P, Reiffers J, Cornelissen JJ, Hughes T, Agis H, Fischer T, Verhoef G, Shepherd J, Saglio G, Gratwohl A, Nielsen JL, Radich JP, Simonsson B, Taylor K, Baccarani M, So C, Letvak L, Larson RA, Investigators I (2006) Five-year followup of patients receiving imatinib for chronic myeloid leukemia. $\mathrm{N}$ Engl J Med 355(23):2408-2417. doi:10.1056/NEJMoa062867

80. Guilhot F, Druker B, Larson RA, Gathmann I, So C, Waltzman R, O'Brien SG (2009) High rates of durable response are achieved with imatinib after treatment with interferon alpha plus cytarabine: results from the International Randomized Study of Interferon and STI571 (IRIS) trial. Haematologica 94(12):1669-1675. doi:10.3324/haematol.2009.010629

81. Hochhaus A, O’Brien SG, Guilhot F, Druker BJ, Branford S, Foroni L, Goldman JM, Muller MC, Radich JP, Rudoltz M, Mone M, Gathmann I, Hughes TP, Larson RA, Investigators I (2009) Six-year follow-up of patients receiving imatinib for the first-line treatment of chronic myeloid leukemia. Leukemia 23(6): 1054-1061. doi:10.1038/leu.2009.38

82. O’Brien SG, Guilhot F, Larson RA, Gathmann I, Baccarani M, Cervantes F, Cornelissen JJ, Fischer T, Hochhaus A, Hughes T, Lechner K, Nielsen JL, Rousselot P, Reiffers J, Saglio G, Shepherd J, Simonsson B, Gratwohl A, Goldman JM, Kantarjian H, Taylor K, Verhoef G, Bolton AE, Capdeville R, Druker BJ, Investigators I (2003) Imatinib compared with interferon and low-dose cytarabine for newly diagnosed chronic-phase chronic myeloid leukemia. N Engl J Med 348(11):994-1004. doi:10.1056 /NEJMoa022457

83. Cameron D, Casey M, Press M, Lindquist D, Pienkowski T, Romieu CG, Chan S, Jagiello-Gruszfeld A, Kaufman B, Crown J, Chan A, Campone M, Viens P, Davidson N, Gorbounova V, Raats JI, Skarlos D, Newstat B, Roychowdhury D, Paoletti P, Oliva C, Rubin S, Stein S, Geyer CE (2008) A phase III randomized comparison of lapatinib plus capecitabine versus capecitabine alone in women with advanced breast cancer that has progressed on trastuzumab: updated efficacy and biomarker analyses. Breast Cancer Res Treat 112(3):533-543. doi:10.1007/s10549-0079885-0

84. Decensi A, Puntoni M, Pruneri G, Guerrieri-Gonzaga A, Lazzeroni M, Serrano D, Macis D, Johansson H, Pala O, Luini A, Veronesi P, Galimberti V, Dotti MC, Viale G, Bonanni B (2011) Lapatinib activity in premalignant lesions and HER-2positive cancer of the breast in a randomized, placebo-controlled presurgical trial. Cancer Prev Res (Phila) 4(8):1181-1189. doi:10.1158/1940-6207.capr-10-0337

85. Di Leo A, Gomez HL, Aziz Z, Zvirbule Z, Bines J, Arbushites MC, Guerrera SF, Koehler M, Oliva C, Stein SH, Williams LS, Dering J, Finn RS, Press MF (2008) Phase III, double-blind, randomized study comparing lapatinib plus paclitaxel with placebo plus paclitaxel as first-line treatment for metastatic breast cancer. J Clin Oncol Off J Am Soc Clin Oncol 26(34):5544-5552. doi:10.1200/jco.2008.16.2578

86. Goss PE, Smith IE, O'Shaughnessy J, Ejlertsen B, Kaufmann M, Boyle F, Buzdar AU, Fumoleau P, Gradishar W, Martin M, Moy B, Piccart-Gebhart M, Pritchard KI, Lindquist D, Chavarri-Guerra Y, Aktan G, Rappold E, Williams LS, Finkelstein DM, investigators T (2013) Adjuvant lapatinib for women with early-stage HER2-positive breast cancer: a randomised, controlled, phase 3 trial. Lancet Oncol 14(1):88-96. doi:10.1016/S1470-2045(12 70508-9

87. Guan Z, Xu B, DeSilvio ML, Shen Z, Arpornwirat W, Tong Z, Lorvidhaya V, Jiang Z, Yang J, Makhson A, Leung WL, Russo MW, Newstat B, Wang L, Chen G, Oliva C, Gomez H (2013) Randomized trial of lapatinib versus placebo added to paclitaxel in the treatment of human epidermal growth factor receptor 2overexpressing metastatic breast cancer. J Clin Oncol Off J Am 
Soc Clin Oncol 31(16):1947-1953. doi:10.1200 /jco.2011.40.5241

88. Johnston S, Pippen J Jr, Pivot X, Lichinitser M, Sadeghi S, Dieras V, Gomez HL, Romieu G, Manikhas A, Kennedy MJ, Press MF, Maltzman J, Florance A, O'Rourke L, Oliva C, Stein S, Pegram M (2009) Lapatinib combined with letrozole versus letrozole and placebo as first-line therapy for postmenopausal hormone receptor-positive metastatic breast cancer. J Clin Oncol Off J Am Soc Clin Oncol 27(33):5538-5546. doi:10.1200 jjco.2009.23.3734

89. Aviles A, Nambo MJ, Neri N, Cleto S, Castaneda C, HuertaGuzman J, Murillo E, Contreras M, Talavera A, Gonzalez M (2007) Dose dense (CEOP-14) vs dose dense and rituximab (CEOP-14 + R) in high-risk diffuse large cell lymphoma. Med Oncol 24(1):85-89

90. Aviles A, Nambo MJ, Castaneda C, Cleto S, Neri N, Murillo E, Huerta-Guzman J, Contreras M (2007) Rituximab and escalated chemotherapy in elderly patients with aggressive diffuse large-cell lymphoma: a controlled clinical trial. Cancer Biother Radiopharm 22(2):194-199. doi:10.1089/cbr.2006.360

91. Buske C, Hoster E, Dreyling M, Eimermacher H, Wandt H, Metzner B, Fuchs R, Bittenbring J, Woermann B, Hohloch K, Hess G, Ludwig WD, Schimke J, Schmitz S, Kneba M, Reiser M, Graeven U, Klapper W, Unterhalt M, Hiddemann W (2009) The addition of rituximab to front-line therapy with CHOP (R$\mathrm{CHOP}$ ) results in a higher response rate and longer time to treatment failure in patients with lymphoplasmacytic lymphoma: results of a randomized trial of the German Low-Grade Lymphoma Study Group (GLSG). Leukemia 23(1):153-161. doi:10.1038 /leu.2008.261

92. Coiffier B, Lepage E, Briere J, Herbrecht R, Tilly H, Bouabdallah R, Morel P, Van Den Neste E, Salles G, Gaulard P, Reyes F, Lederlin P, Gisselbrecht C (2002) CHOP chemotherapy plus rituximab compared with CHOP alone in elderly patients with diffuse large-B-cell lymphoma. N Engl J Med 346(4):235-242. doi:10.1056/NEJMoa011795

93. Coiffier B, Thieblemont C, Van Den Neste E, Lepeu G, Plantier I, Castaigne S, Lefort S, Marit G, Macro M, Sebban C, Belhadj K, Bordessoule D, Ferme C, Tilly H (2010) Long-term outcome of patients in the LNH-98.5 trial, the first randomized study comparing rituximab-CHOP to standard CHOP chemotherapy in DLBCL patients: a study by the Groupe d'Etudes des Lymphomes de l'Adulte. Blood 116(12):2040-2045. doi:10.1182/blood-201003-276246

94. Eve HE, Linch D, Qian W, Ross M, Seymour JF, Smith P, Stevens L, Rule SA (2009) Toxicity of fludarabine and cyclophosphamide with or without rituximab as initial therapy for patients with previously untreated mantle cell lymphoma: results of a randomised phase II study. Leuk Lymphoma 50(2):211-215. doi:10.1080 /10428190802688509

95. Feugier P, Van Hoof A, Sebban C, Solal-Celigny P, Bouabdallah R, Ferme C, Christian B, Lepage E, Tilly H, Morschhauser F, Gaulard P, Salles G, Bosly A, Gisselbrecht C, Reyes F, Coiffier B (2005) Long-term results of the R-CHOP study in the treatment of elderly patients with diffuse large B-cell lymphoma: a study by the Groupe d'Etude des Lymphomes de l'Adulte. Journal of clinical oncology: official journal of the American Society of Clinical Oncology 23(18):4117-4126. doi:10.1200/jco.2005.09.131

96. Forstpointner R, Dreyling M, Repp R, Hermann S, Hanel A, Metzner B, Pott C, Hartmann F, Rothmann F, Rohrberg R, Bock HP, Wandt H, Unterhalt M, Hiddemann W, German Low-Grade Lymphoma Study G (2004) The addition of rituximab to a combination of fludarabine, cyclophosphamide, mitoxantrone (FCM) significantly increases the response rate and prolongs survival as compared with FCM alone in patients with relapsed and refractory follicular and mantle cell lymphomas: results of a prospective randomized study of the German Low-Grade Lymphoma Study Group. Blood 104(10):3064-3071. doi:10.1182/blood-2004-041323

97. Forstpointner R, Unterhalt M, Dreyling M, Bock HP, Repp R, Wandt H, Pott C, Seymour JF, Metzner B, Hanel A, Lehmann T, Hartmann F, Einsele H, Hiddemann W, German Low Grade Lymphoma Study G (2006) Maintenance therapy with rituximab leads to a significant prolongation of response duration after salvage therapy with a combination of rituximab, fludarabine, cyclophosphamide, and mitoxantrone (R-FCM) in patients with recurring and refractory follicular and mantle cell lymphomas: results of a prospective randomized study of the German Low Grade Lymphoma Study Group (GLSG). Blood 108(13):4003-4008. doi:10.1182/blood-2006-04-016725

98. Ghielmini M, Schmitz SF, Cogliatti SB, Pichert G, Hummerjohann J, Waltzer U, Fey MF, Betticher DC, Martinelli G, Peccatori F, Hess U, Zucca E, Stupp R, Kovacsovics T, Helg C, Lohri A, Bargetzi M, Vorobiof D, Cerny T (2004) Prolonged treatment with rituximab in patients with follicular lymphoma significantly increases event-free survival and response duration compared with the standard weekly $\times 4$ schedule. Blood 103(12): 4416-4423. doi:10.1182/blood-2003-10-3411

99. Ghielmini M, Schmitz SF, Cogliatti S, Bertoni F, Waltzer U, Fey MF, Betticher DC, Schefer H, Pichert G, Stahel R, Ketterer N, Bargetzi M, Cerny T, Swiss Group for Clinical Cancer R (2005) Effect of single-agent rituximab given at the standard schedule or as prolonged treatment in patients with mantle cell lymphoma: a study of the Swiss Group for Clinical Cancer Research (SAKK). J Clin Oncol 23(4):705-711. doi:10.1200/JCO.2005.04.164

100. Gisselbrecht C, Schmitz N, Mounier N, Singh Gill D, Linch DC, Trneny M, Bosly A, Milpied NJ, Radford J, Ketterer N, Shpilberg O, Duhrsen U, Hagberg H, Ma DD, Viardot A, Lowenthal R, Briere J, Salles G, Moskowitz CH, Glass B (2012) Rituximab maintenance therapy after autologous stem-cell transplantation in patients with relapsed CD20(+) diffuse large B-cell lymphoma: final analysis of the collaborative trial in relapsed aggressive lymphoma. J Clin Oncol Off J Am Soc Clin Oncol 30(36):4462-4469. doi:10.1200/jco.2012.41.9416

101. Habermann TM, Weller EA, Morrison VA, Gascoyne RD, Cassileth PA, Cohn JB, Dakhil SR, Woda B, Fisher RI, Peterson BA, Horning SJ (2006) Rituximab-CHOP versus CHOP alone or with maintenance rituximab in older patients with diffuse large Bcell lymphoma. J Clin Oncol Off J Am Soc Clin Oncol 24(19): 3121-3127. doi:10.1200/jco.2005.05.1003

102. Haioun C, Mounier N, Emile JF, Ranta D, Coiffier B, Tilly H, Recher C, Ferme C, Gabarre J, Herbrecht R, Morchhauser F, Gisselbrecht C (2009) Rituximab versus observation after highdose consolidative first-line chemotherapy with autologous stemcell transplantation in patients with poor-risk diffuse large B-cell lymphoma. Ann Oncol 20(12):1985-1992. doi:10.1093 /annonc/mdp237

103. Herold M, Haas A, Srock S, Neser S, Al-Ali KH, Neubauer A, Dolken G, Naumann R, Knauf W, Freund M, Rohrberg R, Hoffken K, Franke A, Ittel T, Kettner E, Haak U, Mey U, Klinkenstein C, Assmann M, von Grunhagen U, East German Study Group H, Oncology S (2007) Rituximab added to firstline mitoxantrone, chlorambucil, and prednisolone chemotherapy followed by interferon maintenance prolongs survival in patients with advanced follicular lymphoma: an east German study group hematology and oncology study. J Clin Oncol 25(15):1986-1992. doi:10.1200/JCO.2006.06.4618

104. Hiddemann W, Kneba M, Dreyling M, Schmitz N, Lengfelder E, Schmits R, Reiser M, Metzner B, Harder H, Hegewisch-Becker S, Fischer T, Kropff M, Reis HE, Freund M, Wormann B, Fuchs R, Planker M, Schimke J, Eimermacher H, Trumper L, Aldaoud A, Parwaresch R, Unterhalt M (2005) Frontline therapy with rituximab 
added to the combination of cyclophosphamide, doxorubicin, vincristine, and prednisone (CHOP) significantly improves the outcome for patients with advanced-stage follicular lymphoma compared with therapy with CHOP alone: results of a prospective randomized study of the German Low-Grade Lymphoma Study Group. Blood 106(12): 3725-3732. doi:10.1182/blood-2005-01-0016

105. Kaplan LD, Lee JY, Ambinder RF, Sparano JA, Cesarman E, Chadburn A, Levine AM, Scadden DT (2005) Rituximab does not improve clinical outcome in a randomized phase 3 trial of $\mathrm{CHOP}$ with or without rituximab in patients with HIV-associated non-Hodgkin lymphoma: AIDS-Malignancies Consortium Trial 010. Blood 106(5):1538-1543. doi:10.1182/blood-2005-04-1437

106. Ketterer N, Coiffier B, Thieblemont C, Ferme C, Briere J, Casasnovas O, Bologna S, Christian B, Connerotte T, Recher C, Bordessoule D, Fruchart C, Delarue R, Bonnet C, Morschhauser F, Anglaret B, Soussain C, Fabiani B, Tilly H, Haioun C (2013) Phase III study of ACVBP versus ACVBP plus rituximab for patients with localized low-risk diffuse large B-cell lymphoma (LNH03-1B). Ann Oncol 24(4):1032-1037. doi:10.1093 /annonc/mds600

107. Lenz G, Dreyling M, Hoster E, Wormann B, Duhrsen U, Metzner B, Eimermacher H, Neubauer A, Wandt H, Steinhauer H, Martin S, Heidemann E, Aldaoud A, Parwaresch R, Hasford J, Unterhalt M, Hiddemann W (2005) Immunochemotherapy with rituximab and cyclophosphamide, doxorubicin, vincristine, and prednisone significantly improves response and time to treatment failure, but not long-term outcome in patients with previously untreated mantle cell lymphoma: results of a prospective randomized trial of the German Low Grade Lymphoma Study Group (GLSG). J Clin Oncol Off J Am Soc Clin Oncol 23(9):1984-1992. doi:10.1200 /jco.2005.08.133

108. Marcus R, Imrie K, Belch A, Cunningham D, Flores E, Catalano J, Solal-Celigny P, Offner F, Walewski J, Raposo J, Jack A, Smith P (2005) CVP chemotherapy plus rituximab compared with CVP as first-line treatment for advanced follicular lymphoma. Blood 105(4):1417-1423. doi:10.1182/blood-2004-08-3175

109. Pfreundschuh M, Trumper L, Osterborg A, Pettengell R, Trneny M, Imrie K, Ma D, Gill D, Walewski J, Zinzani PL, Stahel R, Kvaloy S, Shpilberg O, Jaeger U, Hansen M, Lehtinen T, LopezGuillermo A, Corrado C, Scheliga A, Milpied N, Mendila M, Rashford M, Kuhnt E, Loeffler M, MabThera International Trial G (2006) CHOP-like chemotherapy plus rituximab versus CHOPlike chemotherapy alone in young patients with good-prognosis diffuse large-B-cell lymphoma: a randomised controlled trial by the MabThera International Trial (MInT) Group. Lancet Oncol 7(5):379-391. doi:10.1016/S1470-2045(06)70664-7

110. Pfreundschuh M, Schubert J, Ziepert M, Schmits R, Mohren M, Lengfelder E, Reiser M, Nickenig C, Clemens M, Peter N, Bokemeyer C, Eimermacher H, Ho A, Hoffmann M, Mertelsmann R, Trumper L, Balleisen L, Liersch R, Metzner B, Hartmann F, Glass B, Poeschel V, Schmitz N, Ruebe C, Feller AC, Loeffler M, German High-Grade Non-Hodgkin Lymphoma Study G (2008) Six versus eight cycles of bi-weekly CHOP-14 with or without rituximab in elderly patients with aggressive CD20+ Bcell lymphomas: a randomised controlled trial (RICOVER-60). Lancet Oncol 9(2):105-116. doi:10.1016/S1470-2045(08)700020

111. Robak T, Dmoszynska A, Solal-Celigny P, Warzocha K, Loscertales J, Catalano J, Afanasiev BV, Larratt L, Geisler CH, Montillo M, Zyuzgin I, Ganly PS, Dartigeas C, Rosta A, Maurer J, Mendila M, Saville MW, Valente N, Wenger MK, Moiseev SI (2010) Rituximab plus fludarabine and cyclophosphamide prolongs progression-free survival compared with fludarabine and cyclophosphamide alone in previously treated chronic lymphocytic leukemia. J Clin Oncol Off J Am Soc Clin Oncol 28(10): 1756-1765. doi:10.1200/jco.2009.26.4556
112. Salles G, Mounier N, de Guibert S, Morschhauser F, Doyen C, Rossi JF, Haioun C, Brice P, Mahe B, Bouabdallah R, Audhuy B, Ferme C, Dartigeas C, Feugier P, Sebban C, Xerri L, Foussard C (2008) Rituximab combined with chemotherapy and interferon in follicular lymphoma patients: results of the GELA-GOELAMS FL2000 study. Blood 112(13):4824-4831. doi:10.1182/blood2008-04-153189

113. Salles G, Seymour JF, Offner F, Lopez-Guillermo A, Belada D, Xerri L, Feugier P, Bouabdallah R, Catalano JV, Brice P, Caballero D, Haioun C, Pedersen LM, Delmer A, Simpson D, Leppa S, Soubeyran P, Hagenbeek A, Casasnovas O, Intragumtornchai T, Ferme C, da Silva MG, Sebban C, Lister A, Estell JA, Milone G, Sonet A, Mendila M, Coiffier B, Tilly H (2011) Rituximab maintenance for 2 years in patients with high tumour burden follicular lymphoma responding to rituximab plus chemotherapy (PRIMA): a phase 3, randomised controlled trial. Lancet 377(9759):42-51. doi:10.1016/s0140-6736(10)62175-7

114. Sieniawski M, Staak O, Glossmann JP, Reineke T, Scheuss H, Diehl V, Engert A, Josting A (2007) Rituximab added to an intensified salvage chemotherapy program followed by autologous stem cell transplantation improved the outcome in relapsed and refractory aggressive non-Hodgkin lymphoma. Ann Hematol 86(2):107-115. doi:10.1007/s00277-006-0210-5

115. van Oers MH, Klasa R, Marcus RE, Wolf M, Kimby E, Gascoyne RD, Jack A, Van't Veer M, Vranovsky A, Holte H, van Glabbeke M, Teodorovic I, Rozewicz C, Hagenbeek A (2006) Rituximab maintenance improves clinical outcome of relapsed/resistant follicular non-Hodgkin lymphoma in patients both with and without rituximab during induction: results of a prospective randomized phase 3 intergroup trial. Blood 108(10):3295-3301. doi:10.1182 /blood-2006-05-021113

116. van Oers MH, Van Glabbeke M, Giurgea L, Klasa R, Marcus RE, Wolf M, Kimby E, van t Veer M, Vranovsky A, Holte H, Hagenbeek A (2010) Rituximab maintenance treatment of relapsed/resistant follicular non-Hodgkin's lymphoma: long-term outcome of the EORTC 20981 phase III randomized intergroup study. J Clin Oncol Off J Am Soc Clin Oncol 28(17):2853-2858. doi:10.1200/jco.2009.26.5827

117. Zucca E, Conconi A, Laszlo D, Lopez-Guillermo A, Bouabdallah R, Coiffier B, Sebban C, Jardin F, Vitolo U, Morschhauser F, Pileri SA, Copie-Bergman C, Campo E, Jack A, Floriani I, Johnson P, Martelli M, Cavalli F, Martinelli G, Thieblemont C (2013) Addition of rituximab to chlorambucil produces superior eventfree survival in the treatment of patients with extranodal marginalzone B-cell lymphoma: 5-year analysis of the IELSG-19 randomized study. J Clin Oncol Off J Am Soc Clin Oncol 31(5):565-572. doi:10.1200/jco.2011.40.6272

118. Abou-Alfa GK, Johnson P, Knox JJ, Capanu M, Davidenko I, Lacava J, Leung T, Gansukh B, Saltz LB (2010) Doxorubicin plus sorafenib vs doxorubicin alone in patients with advanced hepatocellular carcinoma: a randomized trial. JAMA 304(19):21542160. doi:10.1001/jama.2010.1672

119. Cheng AL, Kang YK, Chen Z, Tsao CJ, Qin S, Kim JS, Luo R, Feng J, Ye S, Yang TS, Xu J, Sun Y, Liang H, Liu J, Wang J, Tak WY, Pan H, Burock K, Zou J, Voliotis D, Guan Z (2009) Efficacy and safety of sorafenib in patients in the Asia-Pacific region with advanced hepatocellular carcinoma: a phase III randomised, double-blind, placebo-controlled trial. Lancet Oncol 10(1):25-34. doi:10.1016/s1470-2045(08)70285-7

120. Escudier B, Eisen T, Stadler WM, Szczylik C, Oudard S, Staehler M, Negrier S, Chevreau C, Desai AA, Rolland F, Demkow T, Hutson TE, Gore M, Anderson S, Hofilena G, Shan M, Pena C, Lathia C, Bukowski RM (2009) Sorafenib for treatment of renal cell carcinoma: final efficacy and safety results of the phase III treatment approaches in renal cancer global evaluation trial. J Clin 
Oncol Off J Am Soc Clin Oncol 27(20):3312-3318. doi:10.1200 /jco.2008.19.5511

121. Escudier B, Szczylik C, Hutson TE, Demkow T, Staehler M, Rolland F, Negrier S, Laferriere N, Scheuring UJ, Cella D, Shah S, Bukowski RM (2009) Randomized phase II trial of first-line treatment with sorafenib versus interferon Alfa-2a in patients with metastatic renal cell carcinoma. J Clin Oncol Off J Am Soc Clin Oncol 27(8):1280-1289. doi:10.1200/jco.2008.19.3342

122. Kudo M, Imanaka K, Chida N, Nakachi K, Tak WY, Takayama T, Yoon JH, Hori T, Kumada H, Hayashi N, Kaneko S, Tsubouchi H, Suh DJ, Furuse J, Okusaka T, Tanaka K, Matsui O, Wada M, Yamaguchi I, Ohya T, Meinhardt G, Okita K (2011) Phase III study of sorafenib after transarterial chemoembolisation in Japanese and Korean patients with unresectable hepatocellular carcinoma. Eur J Cancer 47(14):2117-2127. doi:10.1016/j. ejca.2011.05.007

123. Llovet JM, Ricci S, Mazzaferro V, Hilgard P, Gane E, Blanc JF, de Oliveira AC, Santoro A, Raoul JL, Forner A, Schwartz M, Porta C, Zeuzem S, Bolondi L, Greten TF, Galle PR, Seitz JF, Borbath I, Haussinger D, Giannaris T, Shan M, Moscovici M, Voliotis D, Bruix J (2008) Sorafenib in advanced hepatocellular carcinoma. N Engl J Med 359(4):378-390. doi:10.1056/NEJMoa0708857

124. Rimassa L, Pressiani T, Boni C, Carnaghi C, Rota Caremoli E, Fagiuoli S, Foa P, Salvagni S, Cortesi E, Chiara Tronconi M, Personeni N, Bozzarelli S, Chiara Banzi M, Fanello S, Romano Lutman F, Giordano L, Santoro A (2013) A phase II randomized dose escalation trial of sorafenib in patients with advanced hepatocellular carcinoma. Oncologist 18(4):379-380. doi:10.1634 /theoncologist.2012-0221

125. Sansonno D, Lauletta G, Russi S, Conteduca V, Sansonno L, Dammacco F (2012) Transarterial chemoembolization plus sorafenib: a sequential therapeutic scheme for HCV-related intermediate-stage hepatocellular carcinoma: a randomized clinical trial. Oncologist 17(3):359-366. doi:10.1634/theoncologist.2011-0313

126. Demetri GD, van Oosterom AT, Garrett CR, Blackstein ME, Shah MH, Verweij J, McArthur G, Judson IR, Heinrich MC, Morgan JA, Desai J, Fletcher CD, George S, Bello CL, Huang X, Baum CM, Casali PG (2006) Efficacy and safety of sunitinib in patients with advanced gastrointestinal stromal tumour after failure of imatinib: a randomised controlled trial. Lancet 368(9544):1329-1338. doi:10.1016/s0140-6736(06)69446-4

127. Demetri GD, Garrett CR, Schoffski P, Shah MH, Verweij J, Leyvraz S, Hurwitz HI, Pousa AL, Le Cesne A, Goldstein D, Paz-Ares L, Blay JY, McArthur GA, Xu QC, Huang X, Harmon CS, Tassell V, Cohen DP, Casali PG (2012) Complete longitudinal analyses of the randomized, placebo-controlled, phase III trial of sunitinib in patients with gastrointestinal stromal tumor following imatinib failure. Clin Cancer Res 18(11):3170-3179. doi:10.1158 /1078-0432.ccr-11-3005

128. Motzer RJ, Hutson TE, Tomczak P, Michaelson MD, Bukowski RM, Oudard S, Negrier S, Szczylik C, Pili R, Bjarnason GA, Garcia-del-Muro X, Sosman JA, Solska E, Wilding G, Thompson JA, Kim ST, Chen I, Huang X, Figlin RA (2009) Overall survival and updated results for sunitinib compared with interferon alfa in patients with metastatic renal cell carcinoma. J Clin Oncol Off J Am Soc Clin Oncol 27(22):3584-3590. doi:10.1200/jco.2008.20.1293

129. Buzdar AU, Ibrahim NK, Francis D, Booser DJ, Thomas ES, Theriault RL, Pusztai L, Green MC, Arun BK, Giordano SH, Cristofanilli M, Frye DK, Smith TL, Hunt KK, Singletary SE, Sahin AA, Ewer MS, Buchholz TA, Berry D, Hortobagyi GN (2005) Significantly higher pathologic complete remission rate after neoadjuvant therapy with trastuzumab, paclitaxel, and epirubicin chemotherapy: results of a randomized trial in human epidermal growth factor receptor 2-positive operable breast cancer. J Clin Oncol Off J Am Soc Clin Oncol 23(16):36763685. doi:10.1200/jco.2005.07.032

130. Buzdar AU, Valero V, Ibrahim NK, Francis D, Broglio KR, Theriault RL, Pusztai L, Green MC, Singletary SE, Hunt KK, Sahin AA, Esteva F, Symmans WF, Ewer MS, Buchholz TA, Hortobagyi GN (2007) Neoadjuvant therapy with paclitaxel followed by 5 -fluorouracil, epirubicin, and cyclophosphamide chemotherapy and concurrent trastuzumab in human epidermal growth factor receptor 2-positive operable breast cancer: an update of the initial randomized study population and data of additional patients treated with the same regimen. Clin Cancer Res 13(1):228-233. doi:10.1158/1078-0432.ccr-06-1345

131. Gasparini G, Gion M, Mariani L, Papaldo P, Crivellari D, Filippelli G, Morabito A, Silingardi V, Torino F, Spada A, Zancan M, De Sio L, Caputo A, Cognetti F, Lambiase A, Amadori D (2007) Randomized phase II trial of weekly paclitaxel alone versus trastuzumab plus weekly paclitaxel as first-line therapy of patients with her- 2 positive advanced breast cancer. Breast Cancer Res Treat 101(3):355-365. doi:10.1007/s10549-0069306-9

132. Gianni L, Eiermann W, Semiglazov V, Manikhas A, Lluch A, Tjulandin S, Zambetti M, Vazquez F, Byakhow M, Lichinitser M, Climent MA, Ciruelos E, Ojeda B, Mansutti M, Bozhok A, Baronio R, Feyereislova A, Barton C, Valagussa P, Baselga J (2010) Neoadjuvant chemotherapy with trastuzumab followed by adjuvant trastuzumab versus neoadjuvant chemotherapy alone, in patients with HER2-positive locally advanced breast cancer (the NOAH trial): a randomised controlled superiority trial with a parallel HER2-negative cohort. Lancet 375(9712):377-384. doi:10.1016/s0140-6736(09)61964-4

133. Gianni L, Dafni U, Gelber RD, Azambuja E, Muehlbauer S, Goldhirsch A, Untch M, Smith I, Baselga J, Jackisch C, Cameron D, Mano M, Pedrini JL, Veronesi A, Mendiola C, Pluzanska A, Semiglazov V, Vrdoljak E, Eckart MJ, Shen Z, Skiadopoulos G, Procter M, Pritchard KI, Piccart-Gebhart MJ, Bell R, Herceptin Adjuvant Trial Study T (2011) Treatment with trastuzumab for 1 year after adjuvant chemotherapy in patients with HER2-positive early breast cancer: a 4-year follow-up of a randomised controlled trial. Lancet Oncol 12(3):236-244. doi:10.1016/S1470-2045(11)70033-X

134. Halyard MY, Pisansky TM, Dueck AC, Suman V, Pierce L, Solin L, Marks L, Davidson N, Martino S, Kaufman P, Kutteh L, Dakhil SR, Perez EA (2009) Radiotherapy and adjuvant trastuzumab in operable breast cancer: tolerability and adverse event data from the NCCTG Phase III Trial N9831. J Clin Oncol Off J Am Soc Clin Oncol 27(16):2638-2644. doi:10.1200/jco.2008.17.9549

135. Huober J, Fasching PA, Barsoum M, Petruzelka L, Wallwiener D, Thomssen C, Reimer T, Paepke S, Azim HA, Ragosch V, Kubista E, Baumgartner AK, Beckmann MW, May C, Nimmrich I, Harbeck N (2012) Higher efficacy of letrozole in combination with trastuzumab compared to letrozole monotherapy as firstline treatment in patients with HER2-positive, hormone-receptorpositive metastatic breast cancer-results of the eLEcTRA trial. Breast 21(1):27-33. doi:10.1016/j.breast.2011.07.006

136. Joensuu H, Kellokumpu-Lehtinen PL, Bono P, Alanko T, Kataja V, Asola R, Utriainen T, Kokko R, Hemminki A, Tarkkanen M, Turpeenniemi-Hujanen T, Jyrkkio S, Flander M, Helle L, Ingalsuo S, Johansson K, Jaaskelainen AS, Pajunen M, Rauhala M, KalevaKerola J, Salminen T, Leinonen M, Elomaa I, Isola J, FinHer Study I (2006) Adjuvant docetaxel or vinorelbine with or without trastuzumab for breast cancer. N Engl J Med 354(8):809-820. doi:10.1056/NEJMoa053028

137. Joensuu H, Bono P, Kataja V, Alanko T, Kokko R, Asola R, Utriainen T, Turpeenniemi-Hujanen T, Jyrkkio S, Moykkynen $\mathrm{K}$, Helle L, Ingalsuo S, Pajunen M, Huusko M, Salminen T, Auvinen P, Leinonen H, Leinonen M, Isola J, Kellokumpu- 
Lehtinen PL (2009) Fluorouracil, epirubicin, and cyclophosphamide with either docetaxel or vinorelbine, with or without trastuzumab, as adjuvant treatments of breast cancer: final results of the FinHer Trial. J Clin Oncol Off J Am Soc Clin Oncol 27(34): 5685-5692. doi:10.1200/jco.2008.21.4577

138. Marty M, Cognetti F, Maraninchi D, Snyder R, Mauriac L, Tubiana-Hulin M, Chan S, Grimes D, Anton A, Lluch A, Kennedy J, O'Byrne K, Conte P, Green M, Ward C, Mayne K, Extra JM (2005) Randomized phase II trial of the efficacy and safety of trastuzumab combined with docetaxel in patients with human epidermal growth factor receptor 2-positive metastatic breast cancer administered as first-line treatment: the M77001 study group. J Clin Oncol Off J Am Soc Clin Oncol 23(19): 4265-4274. doi:10.1200/jco.2005.04.173

139. Piccart-Gebhart MJ, Procter M, Leyland-Jones B, Goldhirsch A, Untch M, Smith I, Gianni L, Baselga J, Bell R, Jackisch C, Cameron D, Dowsett M, Barrios CH, Steger G, Huang CS, Andersson M, Inbar M, Lichinitser M, Lang I, Nitz U, Iwata H, Thomssen C, Lohrisch C, Suter TM, Ruschoff J, Suto T, Greatorex V, Ward C, Straehle C, McFadden E, Dolci MS, Gelber RD, Herceptin Adjuvant Trial Study T (2005) Trastuzumab after adjuvant chemotherapy in HER2-positive breast cancer. N Engl J Med 353(16):1659-1672. doi:10.1056/NEJMoa052306

140. Procter M, Suter TM, de Azambuja E, Dafni U, van Dooren V, Muehlbauer S, Climent MA, Rechberger E, Liu WT, Toi M, Coombes RC, Dodwell D, Pagani O, Madrid J, Hall M, Chen SC, Focan C, Muschol M, van Veldhuisen DJ, Piccart-Gebhart MJ (2010) Longer-term assessment of trastuzumab-related cardiac adverse events in the Herceptin Adjuvant (HERA) trial. J Clin Oncol Off J Am Soc Clin Oncol 28(21):3422-3428. doi:10.1200 /jco.2009.26.0463

141. Slamon DJ, Leyland-Jones B, Shak S, Fuchs H, Paton V, Bajamonde A, Fleming T, Eiermann W, Wolter J, Pegram M, Baselga J, Norton L (2001) Use of chemotherapy plus a monoclonal antibody against HER2 for metastatic breast cancer that overexpresses HER2. N Engl J Med 344(11):783-792. doi:10.1056/nejm200103153441101

142. Smith I, Procter M, Gelber RD, Guillaume S, Feyereislova A, Dowsett M, Goldhirsch A, Untch M, Mariani G, Baselga J, Kaufmann M, Cameron D, Bell R, Bergh J, Coleman R, Wardley A, Harbeck N, Lopez RI, Mallmann P, Gelmon K, Wilcken N, Wist E, Sanchez Rovira P, Piccart-Gebhart MJ, team Hs (2007) 2-year follow-up of trastuzumab after adjuvant chemotherapy in HER2positive breast cancer: a randomised controlled trial. Lancet 369(9555):29-36. doi:10.1016/S0140-6736(07)60028-2
143. Spielmann M, Roche H, Delozier T, Canon JL, Romieu G, Bourgeois H, Extra JM, Serin D, Kerbrat P, Machiels JP, Lortholary A, Orfeuvre H, Campone M, Hardy-Bessard AC, Coudert B, Maerevoet M, Piot G, Kramar A, Martin AL, Penault-Llorca F (2009) Trastuzumab for patients with axillarynode-positive breast cancer: results of the FNCLCC-PACS 04 trial. J Clin Oncol Off J Am Soc Clin Oncol 27(36):6129-6134. doi:10.1200/jco.2009.23.0946

144. Tan-Chiu E, Yothers G, Romond E, Geyer CE Jr, Ewer M, Keefe D, Shannon RP, Swain SM, Brown A, Fehrenbacher L, Vogel VG, Seay TE, Rastogi P, Mamounas EP, Wolmark N, Bryant J (2005) Assessment of cardiac dysfunction in a randomized trial comparing doxorubicin and cyclophosphamide followed by paclitaxel, with or without trastuzumab as adjuvant therapy in node-positive, human epidermal growth factor receptor 2-overexpressing breast cancer: NSABP B-31. J Clin Oncol Off J Am Soc Clin Oncol 23(31):7811-7819. doi:10.1200/jco.2005.02.4091

145. Sackett DL, Strauss SE, Richardson WS, et al (2000) Evidencebased medicine: how to practice and teach EBM, 2nd edn. Churchill Livingstone, Edinburgh

146. Richards CJ, Je Y, Schutz FA, Heng DY, Dallabrida SM, Moslehi JJ, Choueiri TK (2011) Incidence and risk of congestive heart failure in patients with renal and nonrenal cell carcinoma treated with sunitinib. J Clin Oncol Off J Am Soc Clin Oncol 29(25): 3450-3456. doi:10.1200/jco.2010.34.4309

147. Balduzzi S, Mantarro S, Guarneri V, Tagliabue L, Pistotti V, Moja L, D'Amico R (2014) Trastuzumab-containing regimens for metastatic breast cancer. Cochrane Database Syst Rev 6:Cd006242. doi:10.1002/14651858.CD006242.pub2

148. Funakoshi T, Latif A, Galsky MD (2013) Risk of hypertension in cancer patients treated with sorafenib: an updated systematic review and meta-analysis. J Hum Hypertens 27(10):601-611. doi:10.1038/jhh.2013.30

149. Abdel-Rahman O, Fouad M (2014) Risk of cardiovascular toxicities in patients with solid tumors treated with sorafenib: an updated systematic review and meta-analysis. Future Oncol 10(12): 1981-1992. doi:10.2217/fon.14.42

150. Thornton K, Kim G, Maher VE, Chattopadhyay S, Tang S, Moon YJ, Song P, Marathe A, Balakrishnan S, Zhu H, Garnett C, Liu Q, Booth B, Gehrke B, Dorsam R, Verbois L, Ghosh D, Wilson W, Duan J, Sarker H, Miksinski SP, Skarupa L, Ibrahim A, Justice R, Murgo A, Pazdur R (2012) Vandetanib for the treatment of symptomatic or progressive medullary thyroid cancer in patients with unresectable locally advanced or metastatic disease: U.S. Food and Drug Administration drug approval summary. Clin Cancer Res 18(14): 3722-3730. doi:10.1158/1078-0432.ccr-12-0411 